REVIEW OF HISTORICAL SCIENCES 2017, VOL. XVI, NO. 3

http://dx.doi.org/10.18778/1644-857X.16.03.03

ZBigniew ANUSIK

UnIVERSity OF LODZ*

\title{
The Commonwealth of Poland towards Russia in the final stage of the Great Diet (1791-1792)
}

Summary. When the Constitution was ratified on May 3, 1791, establishing good relations with Russia was the most important issue for the security of the Commonwealth. As leaders of the Great Diet noticed that prosperous situation in the Polish-Lithuanian state's international relations was ending, they suggested Stanisław August to turn to Russia. Because of their initiative, the king introduced several members of the St. Petersburg court to the Guardians of the Laws. Yet, it did not reorient Polish foreign policy. Having strengthened his position, Stanisław August was delaying direct talks with the empress. He was convinced, that to avoid Russian intervention in the Commonwealth's internal affairs, one should not provoke Russians and appease any internal conflicts. That assumption turned to be wrong, though. Contrary to the views of the vast majority of Polish historians, who believed that Russian intervention in Poland was predetermined, the St. Petersburg court was divided, when it came to the policy on the Polish-Lithuanian state. Some advisers of Catherine II believed, that without a final agreement with German courts, one should not start a war with the Commonwealth, because it would be hard, long-lasting and costly. Yet, views of Polish malcontents and empress's favorite, Platon A. Zubov, were taken into account, and a military operation was launched, without looking at Vienna and Berlin's position. A passive diplomacy turned out to be a fatal mistake of the Polish king and his advisers. The concept of a limited warfare was equally wrong. The weak resistance of the Polish army strengthened the position of the empress's favorite. When Stanisław August's letter to Catherine II arrived at St. Petersburg, already in the course of war, at the Russian court a group of war opponents took a final attempt to stop hostilities, and start negotiations with the Commonwealth's ruler. However, successes of empress's troops, that rapidly moved towards Warsaw after the withdrawing Poles, favored supporters of an armed intervention. The king and his advisers ceased to believe in the possibility of victory too soon, and

* The Faculty of Philosophy and History, The Institute of History, The Department of Modern History / Wydział Filozoficzno-Historyczny, Instytut Historii, Katedra Historii Nowożytnej, e-mail: zanusik@uni.lodz.pl. 
capitulated at the time, when there was still a chance to continue the war, a prolongation of which by several weeks might have prompted the empress to start peace negotiations. It was a great political mistake, which turned out to be the beginning of the end of the First Republic.

Keywords: Great Diet, Constitution of May 3, Guardians of the Laws, foreign policy of the Commonwealth, Russian-Polish relations in 1791-1792.

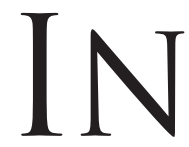
the decade preceding the convening of the Great Diet not only a serious internal crisis was arising in the Commonwealth, but also there was noticed an increasing dissatisfaction with a Russian protectorate. Wide circles of the noble society, represented by a group of non-dependent oppositional deputies in the sejmiks of 1778-1786, formulated clear postulates of the need to defend national dignity, resolve independently (even within the limits of the treaty guarantees) internal problems, take immediate action to strengthen the army, and carry out necessary reforms without Russia's consent. Consequently, it led to the spread of anti-Russian tendencies among noblemen, and forced the "enlightened" faction of magnate's leaders of the opposition to change their own political program. That reorientation was reflected in Czartoryski's and Potocki's republican-patriotic political program, and their noble slogan of defense of the sovereignty of the nation and the state. It seems, that the popularity of patriotic attitudes was not the result of top-down treatments. Quite the contrary, leaders of the Puławy camp seemed to follow the voice of independent deputies, who were representing a considerable part of the noble society, the fact that seems to explain the unparalleled success of an opposition at the beginning of the Great Diet ${ }^{1}$.

First sessions of that Diet belonged to the so called patriots, namely an anti-royalist opposition, that was preaching anti-Russian slogans. Its leaders, having decided on an agreement with

1 See A. Stroynowski, Patriotyczne wystapienia opozycji na sejmie 1778 r., "Acta Universitatis Lodziensis", Folia Historica 19, 1984, pp. 178-179; id e m, Sejmowa opozycja antykrólewska w czasach Rady Nieustajacej (kryteria klasyfikacji), "Acta Universitatis Lodziensis", Folia Historica 18, 1984, p. 26; W. Szczy giels ki, Oświecony elitaryzm w Polsce, "Zeszyty Naukowe Uniwersytetu Łódzkiego", series I, issue 4, 1976, p. 120; J. Mich als ki, "Warszawa", czyli o antystołecznych nastrojach w czasach Stanisława Augusta, [in:] Warszawa XVIII wieku, issue 1, Warszawa 1972, pp. 30-31; Z. A nu sik, Rzeczpospolita wobec wojny wschodniej (1787-1792) i wojny szwedzko-rosyjskiej (1788-1790), [in:] Polska wobec wielkich konfliktów w Europie nowożytnej. $Z$ dziejów dyplomacji $i$ stosunków międzynarodowych w XV-XVIII wieku, ed. R. Skowron, Kraków 2009, pp. 148-149. 
Prussia, openly opposed the Russian ambassador in Warsaw, Otto von Stackelberg, who was defending the Permanent Council so hated by them. Some of them were even eager to ask Prussians for a military aid, only to realize their program. It was just what the Berlin court needed, as at the very moment it intended to conduct the partition of the Commonwealth's lands ${ }^{2}$.

Foundations of the Russian advantage in Poland quickly collapsed as well. On October 13, 1788, in a note written on behalf of his king, a Prussian resident in Warsaw, Ludwig von Buchholtz, pointed at the anti-Prussian character of the Polish-Russian alliance that had been designed since the autumn of 1787. At the same time, he offered deliberating estates an alliance with Fredrick Wilhelm II, which was an alternative to Russian proposals. Thus, Catherine II ceased to insist on the codification of the treaty with the Commonwealth, and Stanisław August began to doubt that there was still a chance of its adoption by the Diet. On October 20, a resolution was written to appoint a hundred thousand troops. On November 3, the Military Department of the Permanent Council was abolished, and a military command over the army was entrusted to the Military Commission, that responded directly to the Diet. On November 19, under the pressure of the patriotic camp, on behalf of his monarch, Buchholtz relinquished guarantees of Polish freedom. Under the treaty of 1775 , the Berlin court and Russia guaranteed a territorial unity of the Commonwealth. On November 29, the Diet announced, that it would take immediate directorship of the country from the date of the abolition of the Permanent Council, that ceased to exist on January $19,1789^{3}$.

An attitude of a current protector of the Commonwealth, Russia, was still of the uttermost importance as regards future of the Diet's work. As it turned out, Austrian diplomacy, represented by

${ }^{2}$ See M. Kucharski, Działalność dyplomacji polskiej $w$ Berlinie $w$ latach 1788-1792, Katowice 2000, pp. 24-25; Z. Anu sik, Stosunki polsko-pruskie w dobie Sejmu Czteroletniego. Kilka refleksji w zwiazku z ksiażka Macieja Kucharskiego, "Przegląd Nauk Historycznych" 2003, vol. II, No. 1 (3), pp. 208-209; idem, Rzeczpospolita wobec wojny..., pp. 150-151.

${ }^{3}$ See W. Kalin ka, Sejm Czteroletni, $4^{\text {th }}$ ed., vol. I, part 1, Kraków 1895, pp. 243250, 256-265, 293-299; W. Szczy gi el s ki, Krytyka parlamentarna Rady Nieustajacej $w$ początkach obrad Sejmu Wielkiego a problem konstytucyjnej reformy władz wykonawczych państwa, "Przegląd Nauk Historycznych" 2003, vol. II, No. 2 (4), pp. 67-110; Z. A nu sik, Wznowienie stosunków dyplomatycznych polsko-szwedzkich u progu obrad Sejmu Czteroletniego, "Acta Universitatis Lodziensis", Folia Historica 49, 1993, pp. 79-80; id e m, Rzeczpospolita wobec wojny..., pp. 151-152. 
a cautious and experienced politician, Wenzel Anton von Kaunitz, persuaded the St. Petersburg court to remain tolerant of emancipatory aspirations of the Poles. Kaunitz underlined, that the Prussians wanted to trigger an armed conflict, which at that time would be very dangerous for both courts being at war with Turkey. Catherine II was willing to accept her ally's suggestion and ostensibly stayed neutral to internal events in the Commonwealth. However, from the Polish point of view, it was more important whether she applied to Polish demands supported by the Prussians (formulated already on November 15, 1788) and withdrew from the Commonwealth's territory all her troops (the decision was taken by the empress in May 1789), and later also military stores ${ }^{4}$.

Taking advantage of a favorable economic situation in the international arena during first sessions of the Diet, the patriotic majority launched a general attack on an organization of international relations of the Commonwealth. It also intended to abolish the existing form of government. Attacks on the Permanent Council began with the critique and subsequent liquidation of its magistrates. After the already mentioned abolition of the Military Department, the Department of Foreign Affairs of the Permanent Council was to be dissolved, too. On December 9, 1788, the Diet appointed new representatives to six major European capitals. However, it was the creation on December 18, of "the deputation for the preparation of guidance for representatives abroad, and the supervision of negotiations with foreign courts", that led to the final victory of the opposition, which deprived the king of control over the Ministry of Foreign Affairs. In such a way the Diet took formal control of foreign policy, and began to supervise the Polish diplomatic service ${ }^{5}$.

When the Deputation of Foreign Affairs was created, marshals of the Confederacy, Stanisław Małachowski and Kazimierz Nestor

${ }^{4}$ See W. Kalinka, op. cit., vol. I, part 2, Kraków 1895, pp. 497-503; R.H. Lord, Drugi rozbiór Polski, Warszawa 1973, pp. 75-79; J. Michals ki, Dyplomacja polska w latach 1764-1795, [in:] Historia dyplomacji polskiej, vol. II (1572-1795), ed. Z. Wójcik, p. 614; Z. Anu sik, Wznowienie stosunków..., p. 80; idem, Rzeczpospolita wobec wojny..., p. 152; D. Nawrot, Działania dyplomacji polskiej $w$ Wiedniu w latach 1788-1792, Katowice 1999, pp. 26-29.

${ }^{5}$ See Volumina legum [further on: VL], vol. IX, Kraków 1889, p. 57, pp. 61-62; Z. Anusik, Misja polska $w$ Sztokholmie $w$ latach 1789-1795, Łódź 1993, p. 18; id e m, Wznowienie stosunków..., p. 81; id e m, Organizacja i funkcjonowanie polskiej służby zagranicznej w latach 1764-1792 (próba nowego spojrzenia), "Acta Universitatis Lodziensis", Folia Historica 58, 1996, pp. 61-65; i d e m, Rzeczpospolita wobec wojny..., pp. 152-153. 
Sapieha, as well as Ignacy Potocki and Bishop of Kujawy, Józef Ignacy Rybiński, influenced its work the most. Ignacy Potocki tried to be a true inspirer and head of the Diet's foreign policy, as he privately corresponded with Polish diplomatic missions. Still, it should be mentioned, that although he was one of the most influential members of the Deputation, his foreign policy was extremely cautious. He consulted all his steps with closest co-workers, and avoided to specify his views on even the most important issues. His diplomatic correspondence was, in fact, only informative, as all political decisions were made by a broader group of Diet's leaders, and any orders resulting from those decisions were sent to foreign Polish diplomatic missions by the Deputation of Foreign Affairs only ${ }^{6}$.

Already at the turn of 1788 and 1789, leaders of the Diet decided to tighten cooperation with Prussia, the fact that should pave the Commonwealth way to the anti-imperial triple alliance of Great Britain, Prussia and Holland. In the spring and summer of 1789 , the patriotic camp, that had the majority in the Diet, was divided into two parts. At that time it turned out, that political paths of "true" (the Puławy camp and Potocki brothers) and "false" (circles of the Crown Grand Hetman, Franciszek Ksawery Branicki) patriots were different. It created the opportunity of an agreement between the "true" patriots and the royalist camp. That cooperation of two factions of new Diet's majority resulted in the signing of an allied treaty between the Commonwealth and Prussia on March 29, 1790. Negotiations with the Berlin court ended at the very moment, when the Prussian king, Frederick William II, decided to start an armed conflict with Austria. The Prussian court was convinced, that after the victorious war the Commonwealth would voluntary resign from Gdańsk, Torun, and a part of Greater Poland. A part of Galicia was offered to the Poles in return, as it was supposed to be taken away from the emperor. It is worth to underline here, that leaders of the Great Diet accepted such a solution (as they hoped to recover entire Galicia), and when the treaty with Prussia was signed, they began preparations for a war with Austria ${ }^{7}$.

${ }^{6}$ See W. Kalinka, op. cit., vol. I, part 1, pp. 335-336; Z. Anusik, A. Stroynowski, Rybinski Józef Ignacy Tadeusz, [in:] Polski słownik biograficzny [further on: PSB], vol. XXXIII, Wrocław-Warszawa-Kraków 1991-1992, pp. 335-336; Z. Anusik, Organizacja i funkcjonowanie..., pp. 65-67; idem, Misja polska..., pp. 53-54; id e m, Rzeczpospolita wobec wojny..., pp. 153-154.

7 See W. Kon o p czyń s ki, Polska a Szwecja. Od pokoju oliwskiego do upadku Rzeczypospolitej 1660-1795, Warszawa 1924, pp. 229-230; S. Askenazy, Przy- 
However, it turned out that the majority of Poles feared the war, especially as the possibility of unspecified territorial concessions to Prussia rose objections, and possible acquisitions could not be as large as it was expected. What is more, already at the end of June 1790, the Berlin court informed Warsaw, that it would not demand from the Commonwealth enforcements provisioned by a treaty. The reason was that Frederick William II's advisers came to the conclusion, that in order to obtain significant territorial concessions from the Poles, Prussia had to take control of Galicia on its own. They believed, that they could demand at least Gdańsk and Torun, if they gave the Commonwealth a part of the Austrian partition. All Prussians' hopes for territorial acquisitions at the expense of the Commonwealth faded away, when on July 27, 1790, the Austrian-Prussian peace treaty was signed in Reichenbach. Unexpectedly, a new German emperor and a ruler of Austria, Leopold II, agreed to conclude peace with Turkey under the status quo ante. It should be added here, that the Reichenbach convention was a complete surprise to the Diet's leaders in Warsaw. Just as surprised by the outcome of talks with the emissaries of the emperor was Frederick William II, who believed that the outbreak of war with Austria was certain ${ }^{8}$.

The news from Reichenbach was badly received in Warsaw. Leaders of the Great Diet feared, that if the Prussian-Austrian con-

mierze polsko-pruskie, $3^{\text {rd }}$ ed., Warszawa 1918, pp. 62-66, 71-74; M. Ku ch ars ki, op. cit., pp. 52-57, 60-67, 73-74; R.H. Lord, op. cit., pp. 84-85; J. Michalski, Dyplomacja polska..., pp. 615-616; D. Naw rot, op. cit., p. 43; Z. An usik, Wznowienie stosunków..., p. 81, pp. 87-92; i d e m, Stosunki polsko-pruskie..., pp. 211 213; idem, Misja polska..., pp. 21-24; idem, Rzeczpospolita wobec wojny..., pp. 155-160. It should be added here, that an alliance with Prussia was harshly criticized by representatives of the so-called Cracow's historical school, and most Polish historians publishing their works after the Second World War. According to them, it was a cardinal political mistake, that ultimately led to the collapse of the Commonwealth. W. Kalinka, B. Dembiński, E. Rostworowski, J. Michalski, and A. Zahorski were of that opinion. In my view, leaders of the Great Diet made a decision to make an alliance with Prussia, although they were perfectly aware of the risk of losing some territories. However, from the very beginning, they treated that alliance purely pragmatically, as a way to become independent of Russia, and have the opportunity to carry out thorough internal reforms.

${ }^{8}$ See M. Kucharski, op. cit., pp. 87-93; J. Michalski, Dyplomacja polska.., p. 642; S. Askenazy, op. cit., pp. 91-95; W. Konopczyński, op. cit., p. 235; Z. Anusik, Stosunki polsko-pruskie..., pp. 215-216; idem, Dyplomacja szwedzka wobec kryzysu monarchii we Francji w latach 1787-1792, Łódź 2000, p. 287; id e m, Rzeczpospolita wobec wojny..., pp. 160-161. 
flict ended, the alliance of March 29, 1790, would be no longer needed. Therefore, they did everything to make that alliance as anti-Russian as possible and, thus, make it attractive to the Prussian party. They hoped, that the Prussian court would maintain relations with the Commonwealth, so they promised to give Gdańsk to Berlin in return for signing a trade treaty. However, on September 6, 1790, the Diet passed a resolution that forbade to renounce any territory belonging to the Polish-Lithuanian state, as well as to exchange it for another lands. It undermined plans of the trade treaty with Prussia and United Kingdom, as well as dispelled the Berlin government's hope to annex at least Gdańsk and Torun with the consent of the Poles. As it turned out, the resolution on the "indivisibility of the Commonwealth's territory" negatively affected Polish-Prussian relations for a short time only. An alliance with the Commonwealth was useful for the Berlin court as long as the trilateral conflict with Russia lasted. Warsaw realized too, that it was necessary to activate its own foreign policy and seek support from countries hostile to St. Petersburg. Thus, in the autumn of 1790 , the Polish diplomacy became more active in its works. Representatives of the Commonwealth in Stockholm and Istanbul were conducting negotiations on alliances with Sweden and Turkey, which had been already started without informing the Prussian ally 9 .

Unfortunately, the above-mentioned negotiations failed and did not lead to the conclusion of a formal agreement with any new state. In that situation, at the beginning of 1791, Prussia still remained the only ally of the Commonwealth. Nevertheless, leaders of the Diet were well informed about changing international situation. When at the end of April Berlin declared, that it was not interested in the Commonwealth's participation in war with Russia and recommended neutrality to the Poles, Warsaw quickly realized, that alliance with Prussia was endangered. As internal situation became less favorable to the Commonwealth, leaders of the Great Diet made a coup and on May 3 they enacted a very important Government Act. It is obvious, that the news from Warsaw was

${ }^{9}$ See S. Askenazy, op. cit., pp. 97-103; M. Kucharski, op. cit., pp. 93-95; J. Michalski, Dyplomacja polska..., pp. 642-643; J. Łojek, Geneza i obalenie Konstytucji 3 maja. Polityka zagraniczna Rzeczypospolitej 1787-1792, Lublin 1986, pp. 60-63; Z. Anusik, Stosunki polsko-pruskie..., pp. 216-217; idem, Misja polska..., pp. 90-93; ide m, Rzeczpospolita wobec wojny..., pp. 161-163; Ostatni poseł polski do Porty Ottomańskiej. Akta legacji stambulskiej Franciszka Piotra Potockiego, ed. K. Waliszewski, vol. I, Paris 1894, pp. 170-171. 
badly received in Berlin. It should not be surprising too, that the Prussian king and his ministers avoided any written declarations on that issue. The Prussian government did not intend to help with Polish reforms, because they were contradictory to the interests of the Hohenzollern country from the very beginning. That issue had been well known for a long time and should not be doubted. More importantly, though, a negative attitude of the Prussian ministry to the May Act was certainly noticed by politicians responsible for the Polish foreign policy. Actions taken in Warsaw shortly after the adoption of the new Government Act proved it ${ }^{10}$.

When the Constitution of May 3 was adopted, the organization of the Polish foreign service significantly changed. The Deputation of Foreign Affairs was dissolved as soon as the Guardians of the Laws with the king as its leader was created, and the Vice-Chancellor of Lithuania, Joachim Chreptowicz, was appointed the Minister of Foreign Affairs. In that way Stanisław August became the head of the Polish diplomacy and foreign policy once again. In other words, within two weeks after the new "Government Act's" adoption important decisions as regards the Polish diplomatic service and the foreign policy of the state were made in the capital of the Commonwealth. One may ask a question, why such a radical reorganization of political forces, which resulted in Ignacy Potocki and Stanisław Małachowski, leaders of the patriotic party, being pulled out (for the time only on paper) of the foreign policy, could have taken place in such a short time? The answer seems obvious. Already in mid-May 1791, Warsaw realized, that the London and Berlin

10 See Z. Anusik, Rokowania o polsko-szwedzki traktat sojuszniczy w 1790 roku, "Zapiski Historyczne" 1996, vol. LXI, issue 2-3, pp. 21-44; i d e m, Wznowienie stosunków..., pp. 67-95; ide m, Misja polska..., pp. 90-94, 102-103; idem, O szwedzki alians. Karta $z$ dziejów stosunków politycznych pomiędzy Sztokholmem a Warszawa $w$ dobie Sejmu Czteroletniego, "Acta Universitatis Lodziensis", Folia Historica 57, 1996, pp. 77-106; ide m, Stosunki polsko-pruskie..., pp. 219-220, 223-224; i d e m, Czy dwór berlinski proponował Szwecji udział $w$ drugim rozbiorze Polski? Przyczynek do dziejów stosunków politycznych pomiędzy Sztokholmem, Berlinem $i$ Warszawa $w$ latach 1789-1792, [in:] Oświeceni wobec rozbiorów Polski, ed. J. Grobis, Łódź 1998, pp. 43-63; ide m, O polska koronę. Dwór sztokholmski wobec kwestii sukcesji tronu $w$ Polsce $w$ dobie Sejmu Czteroletniego, [in:] Studia $i$ materiały $z$ dziejów nowożytnych, eds K. Matwijowski, S. Ochmann-Staniszewska, Prace historyczne XIII, Wrocław 1995, pp. 147-167; idem, Szwedzki rywal Fryderyka Augusta. Gustaw III wobec projektów sukcesji tronu w Polsce w latach 1790-1792, "Rocznik Łódzki” 1997, vol. XLIV, pp. 89-115; i de m, Rzeczpospolita wobec wojny..., pp. 163-169; M. Kucharski, op. cit., p. 106; W. Smoleński, Ostatni rok Sejmu Wielkiego, $2^{\text {nd }}$ ed., Kraków 1897, pp. 235-236. 
courts' action directed against Russia had backfired. Thus, the Polish-Prussian alliance signed in March 1790, was to definitively lose its importance. It seems almost certain, that Stanisław August and leaders of the Diet had been aware of the consequences of the collapse of Anglo-Prussian coalition's plans regarding the St. Petersburg court already a month before the date, when Berlin made a final decision on breaking an alliance with the Commonwealth ${ }^{11}$.

The question, who would be a member of the Guardians of the Laws was a very important issue for the future of the foreign policy of the Polish-Lithuanian state. In first days after the enactment of the Government Act it seemed that the Ministry of Foreign Affairs would stay in the hands of one of the Diet's leaders. Jacek Małachowski protested against events of May 3 and 5, and resigned from the post of the Crown Grand Chancellor. Initially, it was prince Adam Kazimierz Czartoryski, who wanted to take over his place. A few days later Stanisław August seriously considered the possibility of entrusting the post to Ignacy Potocki. The developments in the international arena, however, prompted leaders of the patriotic party to withdraw their candidatures to the Grand Crown Seal and to try (together with the king) to persuade Małachowski to return to Warsaw and accept a nomination to the Guardians. It should be noted here, that Stanisław August originally intended to appoint to the Guardians of the Laws four members of the patriotic party (the Bishop of Kujawy, Józef Ignacy Rybiński, Ignacy Potocki, Stanisław Sołtan and Tomasz Ostrowski), and only one opponent to the Government Act (Franciszek Ksawery Branicki). It was only

${ }^{11}$ Already in mid-May 1791, Stanisław August was convinced that an outbreak of the Prussian-Russian war was unlikely. At that time he wrote to Franciszek Bukaty in London: "Although Prussian and Moscow reinforcements are in progress, everybody is convinced that the peace will be made". See Stanisław August to F. Bukaty, Warsaw May 14, 1791, W. Kalinka, Ostatnie lata panowania Stanisława Augusta, $2^{\text {nd }}$ ed., part 2 (Dokumenta do historyi drugiego i trzeciego podziału), Kraków 1891, p. 196. It is difficult to suppose that leaders of the Diet, who were perfectly aware of the importance of the Prussian-Austrian agreement in Reichenbach and its influence on the Polish-Prussian treaty of March 1790, did not realize all the consequences of the collapse of the triple alliance's war plans against St. Petersburg. It is worth quoting here after S. Askenazy, who wrote about the consequences of the collapse of England's and Prussia's war plans against Russia for the Polish-Prussian alliance that "From June 1791, an alliance with the Commonwealth of March 1790, may be considered as non-existent for the king and the Prussian government, abandoned and broken by Prussia, before it was actually broken and converted into an alliance directed against the Commonwealth". See idem, op. cit., p. 159. 
after consultations with leaders of the Diet, that the king changed his original intention and accepted the composition of the Guardians suggested by Hugo Kołłataj. The body in question finally composed of: the Bishop of Cracow, Feliks Turski, who replaced primate Michał Jerzy Poniatowski, the Crown Grand Chancellor, Jacek Małachowski, the Crown Vice-Chancellor, Joachim Chreptowicz, the Grand Marshal of Lithuania, Ignacy Potocki, the Crown Grand Hetman, Franciszek Ksawery Branicki, and the Crown Treasurer, Tomasz Ostrowski. The Marshal of the Diet, Stanisław Małachows$\mathrm{ki}$, was appointed to the Guardians of the Laws ex officio. At his request, the Marshal of the Lithuanian Confederation, Kazimierz Nestor Sapieha, joined that body, too. Thus, three declared Russian allies, Joachim Chreptowicz, Jacek Małachowski, and Franciszek Ksawery Branicki, became one of the closest co-workers of the king. It did not happen without a reason. The composition of the Guardians was to convince the St. Petersburg court that Warsaw was willing to change its current policy and get closer to Russia again. In addition, to make a non-dubious propaganda, both in the country and abroad, leading malcontents were introduced to the Guardians of the Laws (according to the king and his close co-worker, Hugo Kołłątaj), to disorient opponents of the Government Act, neutralize leaders of possible anti-constitutional acts, and supervise their moves. It should be also added, that leaders of the Diet were convinced, that the presence of Ignacy Potocki and Stanisław Małachowski in the Guardians would allow them to control internal, as well as foreign policy of the country ${ }^{12}$.

12 See Stanisław August to F. Bukaty, Warsaw May 7 and 14, 1791, W. Kalinka, Ostatnie lata..., part 2, p. 193, 196; Stanisław August to Augustyn Deboli, Warsaw May 7, 1791, Rok nadziei, rok klęski. $Z$ korespondencji Stanisława Augusta $z$ posłem polskim w Petersburgu Augustynem Deboli, ed. J. Łojek, Warszawa 1974, p. 50; Stanisław August to Maurice Glayre, Warsaw June 21, 1791, Stanislas Poniatowski et Maurice Glayre. Correspondance relative aux partages de la Pologne, ed. E. Mottaz, Paris 1897, p. 265; M. Wolski, Obrona Stanisława Augusta, ed. B. Zaleski, "Rocznik Towarzystwa Historyczno-Literackiego w Paryżu”, vol. 1867, Poznań 1867, p. 112; J. Wojakowski, Straż Praw, Warszawa 1982, pp. 99-100, 108-109; J. Łojek, op. cit., pp. 163-164; E. Rostworows ki, Ostatni król Rzeczypospolitej. Geneza i upadek Konstytucji 3 maja, Warszawa 1966, pp. 229-230; Z. Anu sik, Kontrowersje wokół składu personalnego Straży Praw. Wpływ uwarunkowań międzynarodowych na sytuację wewnętrzna $w$ Rzeczypospolitej w ostatniej fazie obrad Sejmu Czteroletniego, [in:] 200 lat Konstytucji 3 Maja. Materiały z konferencji naukowej, ed. M. Pawlak, Bydgoszcz 1992, pp. 98-100. 
Without going into further details, it should be clearly underlined once again, that members of the Guardians of the Laws were appointed by the king and the Diet's leaders to radically reorganize political forces in Warsaw. As a result, leaders of the Diet, Ignacy Potocki and Stanisław Małachowski among them, ceased (at least formally) to have direct influence on foreign policy. It was undoubtedly a conscious and well thought decision. In mid-May 1791 , leaders of the patriotic party came to the conclusion, that if there was no open conflict between the triple alliance and Catherine II, the alliance with the Commonwealth would be completely worthless for Prussia. Thus, people responsible for the foreign policy of the Polish-Lithuanian state decided, that an agreement with the St. Petersburg court should be an issue of first importance. The king and leaders of the Diet were unanimous on that. In such a situation in mid-May 1791, the most influential politicians of the Great Diet decided that Stanisław August should be responsible for the state's foreign policy, as well as a difficult task of rebuilding relations with the St. Petersburg court ${ }^{13}$.

Yet, no major changes, either in the Polish international policy, or in the organization of the Polish diplomatic service abroad, took place when foreign policy of the Commonwealth started to be a responsibility of the king again. Stanisław August used a specific composition of the Guardians of the Laws as a pretext to completely paralyze activities of that body. As a consequence, the Guardians of the Laws, the body which according to the legislator's concept was to be the king's board of trustees, dealt during its meetings with completely unimportant matters, both in foreign and internal policy of the state ${ }^{14}$. As Bogusław Leśnodorski rightly pointed out few years ago: "The Guardians of the Laws is not a cabinet, neither in the idea, nor in the final legal concept, it could have been transformed into a Cabinet of Ministers in the course of evolution only. It is the "Royal Council", the monarch essentially decides on

13 See Z. Anusik, Organizacja i funkcjonowanie..., pp. 72-74; ide m, Kontrowersje wokół składu..., pp. 96-100; idem, Stosunki polsko-pruskie..., pp. 224225; id e m, Rzeczpospolita wobec wojny..., pp. 169-170; W. S moleń s ki, op. cit., p. 40; S. To mk ow i c z, Z wieku Stanisława Augusta, Kraków 1882, p. 101.

${ }^{14}$ See J. Łojek, op. cit., pp. 160-163, p. 170; J. Wojakowski, op. cit., pp. 96-97, 205-206 (here the wrong argument, that the Guardians of the Laws was some kind of the government coalition consisted of representatives of most powerful parties in the Commonwealth); Z. A n u sik, Kontrowersje wokół składu..., pp. 100-101. 
his own. There is no "Prime Minister", who would be able to give the government a general tone and character. There is no unified "cabinet" policy. Royal decisions may be signed by any minister regardless of his ministry; if one does not sign a document, it may be signed by the other, more submissive to the monarch, and less afraid of responsibility"15. Stanisław August was gradually freeing himself from the influence of the Diet's leaders and he strengthened his ruling power, reduced the importance of the Guardians of the Laws to the minimum, and took full control over the Commonwealth's foreign policy.

Although leaders of the patriotic party did not significantly influence the foreign policy of the state any more, the king and the leading figures of the constitutional camp still shared many views. Stanisław August and the Diet's leaders agreed, for example, on such an important political issue as an attitude towards emigrants, who were conspiring abroad against the Constitution of May 3. After an analysis of actions taken by the Commonwealth's authorities to make malcontents return to the country and submit to the will of the deliberating estates, Władysław Smoleński stated as follows: "The executive power was guilty of helplessness, and the Diet of softness, the king did not help with his actions either. In correspondence and conversations with malcontents of different ranks he undermined the weakness of the government, which tried to be menacing; in half-words he was denying the solidarity with leaders' attitude, and he was sweetening the bitterness of the Diet's resolutions. His conduct, unsuitable for the dignity of the "head of the nation", intensified malcontents obstinacy and disregard of power. At last, the king was making a deliberate effort to save audacious and dangerous people, on whom he was well informed from Deboli's letters"16. Although one should generally agree with the quoted argumentation, it should be clearly stated, that the royal conduct was supported in the Diet by Stanisław Małachowski, Ignacy and Stanisław Kostka Potocki or Tomasz Ostrowski, whose patriotism and attachment to the constitutional principles of May 3 were unquestionable.

In the meantime the situation was changing inexorably to the disadvantage of the Polish-Lithuanian state. In the summer of 1791,

15 B. Leśn od orski, Dzieło Sejmu Czteroletniego (1788-1792). Studium historyczno-prawne, Wrocław 1951, pp. 318-319.

${ }^{16}$ W. Smoleński, op. cit., p. 421. 
the Anglo-Prussian coalition collapsed. On July 26, the allied states accepted all Russia's claims and agreed on annexing by that country all Turkish lands demanded by the empress. The triple alliance de facto ceased to exist after London's and Berlin's capitulation to the St. Petersburg court. Thereafter, from Prussian point of view, an alliance with the Commonwealth was of no importance any more. At that time events in revolutionary France started to increasingly interest Vienna and Berlin, too. On June 23, 1791, the royal family escaping from Paris was arrested in Varennes. The position of Louis XVI as a king was seriously endangered. That fact accelerated negotiations between Austria and Prussia. On July the preliminary treaty was signed in Vienna. On August 4, Austria signed in Sistova a peace treaty with Turkey. On August 27, 1791, the emperor and the king of Prussia proclaimed the famous Pillnitz declaration, that expressed their common interest in the French Revolution's affairs. It is worth noting here, that in the Viennese draft treaty of July 25, there was a paragraph devoted to the Commonwealth. Both German courts declared, that they would not do anything that could change borders of the Commonwealth and threaten its new constitution. Nor would they try to impose their own candidate for the husband of the Elector of Saxony's daughter, Maria Augusta Nepomucen (called the Polish Infant), who was to sit on the Polish throne in the future, and they would invite the Russian court to a new agreement. That paragraph was fully confirmed a month later in the Pillnitz convention. The Prussian-Austrian approach was very well received in Warsaw, where it was considered as a favorable for the Commonwealth's security. In August 1791, however, less promising news came to the capital of the Polish-Lithuanian state. On August 11, the Russian-Turkish draft peace treaty was signed in Galati. The war in the Balkans was interrupted and Catherine II could start thinking of another hiring for her soldiers. What is more, on October 17, 1791, Russia signed in Drottningholm an alliance with Sweden. Although it was directed against revolutionary France, it did not change the fact that Sweden's king, Gustav III, who earlier was considering the idea of an anti-Russian alliance with the Commonwealth, became an ally of Russia's ruler. All in all, from the Commonwealth's point of view in the summer and autumn of 1791 , very disturbing international changes took place ${ }^{17}$.

17 See S. Askenazy, op. cit., pp. 166-173, 179-180; W. Smoleński, op. cit., pp. 240-241; Z. Anusik, Szwedzki rywal..., p. 111; idem, Dyplomacja szwedz- 
In the first months of 1792, there was a series of events, which posed a real threat to the Polish-Lithuanian state. On January 9, a peace treaty of Jassy (signed after preliminary agreements of Galați) ended the Russian-Turkish war. The political situation in Central and Eastern Europe changed radically. Catherine II regained full freedom of movement and major European capitals believed she was prepared to intervene in the Commonwealth. To make matters worse, in the face of deteriorating relations with France, the Vienna court had to make, unfavorable for the Commonwealth, concessions to Berlin. Although on February 7, 1792, an alliance treaty was signed between Austria and Prussia, in which the entirety of the Commonwealth was guaranteed, it did not include any Prussian guarantees for the Government Act. Moreover, the Emperor Leopold II died on March 1, and on April 20, France declared war on his successor. At that point it was clear that Austria, which as the only one of the partitioning powers was prepared to accept Polish constitution, would not be able to support the Commonwealth neither politically, nor military. Almost at the same time, there was a political turmoil in Stockholm. On March 16, Gustav III was assassinated and died from the wound infection on March 29, 1792. Thus, unpredictable ruler, whose actions could significantly impede the implementation of the St. Petersburg's hostile actions directed against the Commonwealth, was eliminated from the political game ${ }^{18}$.

At this point it is worth presenting Russia's position on the events that took place in the Commonwealth after the adoption of the Constitution of May 3. Catherine II was strongly opposed to reforms proposed by the Great Diet. She was also dissatisfied with the news on the Government Act. However, in May 1791, she delayed with

ka..., pp. 354-408, 441-442; id e m, Rzeczpospolita wobec wojny..., p. 170; Curt von Stedingk to Gustav III, St. Petersburg October 24/November 4, 1791, Riksarkivet in Stockholm [further on: RA], Muscovitica vol. 451, no page numbering (this remark applies to other, quoted below, files of Riksarkivet).

18 See W. Kalinka, Polityka dworu austryackiego $w$ sprawie konstytucyi 3 maja, Kraków 1873, pp. 41-43; S. A skenazy, op. cit., pp. 186-190; W. S moleński, op. cit., pp. 236-238, 254-255; B. De m bińs ki, Rosya a rewolucya francuska, Kraków 1896, pp. 21-22, p. 94, 139, pp. 158-159, p. 165, pp. 206-207, p. 211, 213; J. Łoj ek, Misja Debolego w Petersburgu w latach 1787-1792. Z dziejów stosunków polsko-rosyjskich w czasach Sejmu Czteroletniego, Wrocław 1962, pp. 122-124; Z. Anu sik, Misja polska..., pp. 120-121; ide m, Szwedzki rywal..., pp. 114-115; id e m, O polska koronę..., pp. 165-166; i d e m, Rzeczpospolita wobec wojny..., pp. 170-171. 
action, as the outbreak of war with the Anglo-Prussian coalition was a real threat to her. Yet, on May 16/27, she presented the chief commander of the Russian army against Turkey, prince Grigory A. Potemkin, with possible proceedings against the Commonwealth. A first variant provided that Russia would assure the Poles it would not intervene in the Commonwealth's internal affairs, being ready to guarantee all its borders, as well as to sign trade treaty favorable to the Poles. Moreover, she would do everything possible to give Moldova to the Commonwealth, and she would accept the Elector of Saxony as a candidate to the Polish throne, if only he assured that he would not undermine peace with his neighbors. However, she advised to abstain from that step, until more detailed information about the Polish Revolution and the position of the Vienna court came to St. Petersburg. A second variant provided the creation of a re-confederation of opponents of the new constitution. She promised Russia's support for possible leaders of it. According to the third possibility (earlier suggested by Potemkin), Russian troops were to be introduced to the Kiev, Bratslav and Podole voivodships. The empress was even ready to agree on the partition of the Commonwealth by Prussia, provided that Russia was to receive some lands, too. Still, for the time being, all that was a theory. What is most important, the empress allowed the prince of Tauris to take hostile actions against the Commonwealth, only if Prussian troops were to cross its borders. Since it was very unlikely at that time, it was in fact Catherine II, who tried to stop Potemkin from taking any action against the Polish-Lithuanian state. St. Petersburg decided to wait for further developments ${ }^{19}$.

19 See Catherine II to Grigory A. Potemkin, prince of Tauris, Tsarskoye Selo May 16/27, 1791 (rescript), W. Kalinka, Ostatnie lata..., part 2, pp. 120-123. It is worth mentioning here the interpretation of that rescript by Szymon Askenazy: "So it seemed, that the prince of Tauris was given the carte blanche. But everything depended on one major condition: the Polish-Prussian strike, an armed intervention in Russia. The rescript began with those words: "England is preparing to send its fleet to the Baltic Sea, the Mediterranean Sea, the Black See", and an announcement of the Prussian march to Riga. That rescript was dated May 27, 1791. When the empress was signing the document, she was certain that no English ship, no Prussian battalion would threaten Russia any more, that an assault, a strike, was no longer a threat, that it was certain that there would be no war. When she was giving Potemkin a fictitious condition, she made his power of attorney fictitious as well”. See idem, op. cit., p. 182. See also W. S moleński, op. cit., pp. 172-173 (here the May rescript is quoted literally); and J. Łojek, Geneza i obalenie..., pp. 176-177 (here Askenazy's interpretation is supported). 
Potemkin did not have a chance to do anything about the Polish case, because at the time the rescript addressed to him was written, he was at St. Petersburg, where he stayed for the next few months. Both the empress and her favorite, Platon A. Zubov, were preoccupied with Potemkin's behavior, that showed symptoms of a progressive mental illness. It was not, however, an easy task to move Potemkin away from internal affairs, as he was too powerful. Prince of Tauris was not only the commander-in-chief of the army that was fighting with Turkey, but also a politician, who could have played an important role in a restoration of Russian influence in the Commonwealth. At the beginning of 1791 , Potemkin, who had long planned to build a re-confederation and make an annexation of Ukrainian voivodships, contacted the Royal Artillery General in exile, Stanisław Szczęsny Potocki, who was one of the leading opponents (beside Seweryn Rzewuski) of reforms undertaken by the Great Diet. When the Constitution of May 3 was adopted, Potocki turned to prince of Tauris with a proposal to take joint action to overthrow the Great Diet's work. Potemkin showed Potocki's letter to Catherine II. The empress, who had long thought of getting rid of prince of Tauris from St. Petersburg, decided to kill two birds with one stone. On July 18/29, 1791, the ruler of Russia handed Potemkin two new, "most secret" rescripts on his name. In first document she urged him to immediately leave St. Petersburg and join his army to sign a final peace treaty with Turkey. As she knew that the prince was in favor of continuing the war with the Sultan, she prepared very detailed instructions on the terms of future pacification, and the way peace negotiations should be conducted. In second, additional rescript, she referred to Polish affairs. Catherine II allowed Potemkin to oppose to the Constitution of May 3, preferably immediately after the war with Turkey was ended. She suggested, that the prince should ask Potocki and Rzewuski for help, as they should build strong anti-constitutional party in the Commonwealth and then ask Russia for aid. The empress also wrote about the necessity of obtaining Leopold II's consent for the action, and clarifying the position of the Berlin court. The priority was to return to the state of affairs before 1788. If that goal was impossible to achieve, the empress allowed the possibility of a new division of the Commonwealth's lands between its three neighbors. Before the final outcome of those actions, she recommended Polish malcontents to write multiple anti-constitutional manifestos and 
build re-confederation even before Russian troops would cross borders of the Commonwealth. Potemkin was also supposed to provide leaders of the planned anti-constitutional confederation with support for their actions by two imperial courts, but at the same time he should not initiate the Poles into the idea of a new partition. Catherine II also advised the prince of Tauris to summon Szczęsny Potocki to his headquarters in Jassy to discuss the details of the planned actions. Similarly to the May rescript, also here the empress included some impossible conditions that should be met before her taking action in the Commonwealth. The most important of them seems to be the idea of a joint action with the Vienna court. It proved that the St. Petersburg court had not found a final solution to the Polish case, and another rescript for the prince of Tauris was of no political significance, as it did not reveal legitimate intentions of Catherine II. At the beginning of August 1791, Potemkin left St. Petersburg with instructions that postponed to an indefinite future realization of his hostile intentions towards the Commonwealth. Even if he was not definitively disfavored, it was certain that Zubov and his supporters would not allow the prince of Tauris to realize ideas contained in the empress's letter. Thus, one should not be surprised, that an invitation of leaders of Polish malcontents to Jassy was the only move Potemkin was able to make in line with the July rescript. At the beginning of October 1791, Szczęsny Potocki and Seweryn Rzewuski left Vienna to meet the prince of Tauris ${ }^{20}$.

Potocki arrived at Jassy on October 15, 1791. Potemkin, who was ill, left several hours earlier in the direction of Mikołajew. Rzewuski arrived at Jassy the next day. Almost at the same time they heard the news of the death of the prince of Tauris, who died on October $5 / 16$, somewhere in the steppe. For both Poles the news of Potemkin's death was a disaster. With the death of the prince of Tauris the idea, planned for several months, to create an anti-constitutional re-confederation in the Commonwealth with the support of the empress's troops had lost its only promoter. The Russian court decided to wait for further developments. The chief of Potemkin's staff, General Vasyl S. Popov, temporarily took care of both mal-

${ }^{20}$ See E. Rostworowski, Potocki Stanisław Szczęsny, [in:] PSB, vol. XXIX, Wrocław 1984-1985, pp. 192-193; Catherine II to G.A. Potemkin, prince of Tauris, Tsarskoye Selo July 18/29, 1791 (rescript), W. Kalinka, Ostatnie lata..., part 2, pp. 127-132; W. Smoleński, op. cit., pp. 179-182; S. Askenazy, op. cit., pp. 182-183; J. Łojek, Geneza i obalenie..., pp. 177-178. 
contents. He also sent to St. Petersburg Potocki's and Rzewuski's letters addressed directly to the empress. In anticipation for further orders of the ruler of Russia, both magnates left Jassy and moved to Yazlovets, and then to Galicia. In the meantime, the St. Petersburg court decided, that further negotiations with Polish malcontents should be carried out by Alexander A. Bezborodko, a real secret counsellor and an actual head of the Council of Foreign Affairs who, after Potemkin's death, was entrusted with the task to make a definitive peace with the Turks. Bezborodko reached Jassy on November 2/13, 1791. Here waited the Crown Grand Hetman, Franciszek Ksawery Branicki, who had come for his wife's (who had been living with Potemkin for a long time) inheritance from the prince of Tauris. On November 19/30, Szczęsny Potocki and Seweryn Rzewuski appeared at Jassy, as they were summoned by Bezborodko. It should be emphasized, that Alexander A. Bezborodko was in favor of solving the Polish case in agreement with Austria and Prussia. Yet, the Vienna court's opinion was most important for him, and the latter had always declared its support for the Constitution of May 3, and was strongly opposed to an armed intervention in the Commonwealth. Thus, it is not surprising, that no plan of action was decided on after Bezborodko's talks with Polish malcontents. The Russian dignitary avoided to make any obligations as regards Potocki's and Rzewuski's projects. Finally, in January 1792, he advised Catherine II to allow both malcontents to go to St. Petersburg, where details on the Polish plan were to be discussed. The empress agreed to such a solution. As it turned out, it was one of the biggest mistakes of Bezborodko throughout his entire political career ${ }^{21}$.

In first months of 1792 , at the St. Petersburg court a new political system was formed, where a triumvirate of Platon A. Zubov, Arkadiy I. Morkov and Vasyl S. Popov played a decisive role. Polish malcontents, who finally arrived to St. Petersburg in mid-March 1792 , started cooperation with the above-mentioned politicians (thanks to the intermediary of Szymon Kossakowski). It should be noted, that initially influential persons in St. Petersburg were

${ }^{21}$ See Z. Zielińska, Rzewuski Seweryn, [in:] PSB, vol. XXXIV, Wrocław-Warszawa-Kraków 1992-1993, p. 146; E. Rostworowski, Potocki Stanisław..., pp. 193-194; W. Smoleński, op. cit., pp. 187-188, 191-196, p. 303; J. Łojek, Geneza i obalenie..., p. 172, pp. 224-225; Z. Anusik, Rzeczpospolita wobec wojny..., p. 174. 
rather skeptical of the idea of an armed intervention in the Commonwealth. Alexander A. Bezborodko, who returned to the capital of Russia on March 21, 1792, had even more reservations. It turned out, that during his absence Arkadiy I. Morkov became a head of foreign affairs, and Platon A. Zubov started to control the entire state policy. In the hands of Zubov's supporters, who claimed all the ideas originally promoted by prince Grigory A. Potemkin, and from the beginning wanted to take over the Commonwealth's lands, the Polish case became an excuse to deal with political opponents at the empress's court. Thus, Bezborodko, infuriated by the fact that he was moved away from the state's foreign policy, and Polish malcontents were given far-reaching promises, decided (together with his political friends) to oppose Zubov's and Morkov's plans, as he was aware of the fact, that their realization would determine the supremacy of a mighty favorite for a long time ${ }^{22}$.

Bezborodko and his supporters tried to block or delay the implementation of plans on an armed intervention in the Commonwealth during the meeting of the State Council on March 29/April 9, 1792. Although a draft declaration on the Polish case and the content

${ }^{22}$ See W. Smoleński, op. cit., pp. 303-307; J. Łojek, Geneza i obalenie..., pp. 224-225, 264-266; Z. Anusik, Rzeczpospolita wobec wojny..., pp. 175-176. E. Rostworowski, A. Zahorski, and Z. Zielińska present in their works different views on the policy of the St. Petersburg court towards Poland. Views of those authors are expressed by the following statement of J. Michalski: "Catherine II was more and more into the partition of Poland proposed by most of her advisers, who feared that a return to the situation of 1775-1788 would expose the exhausted state to new serious international conflicts, especially with Prussia. The incorporation of Ukrainian voivodships, after bad experiences of the closure of the passage and the acquisition of areas between the Boh and the Dniester, was becoming a raison d'état. Yet, Catherine II was not entirely in favor of that variant, because of her far-reaching ambitions of extending influence over the entire Commonwealth, as well as antipathy to Prussia for their policy between 1788-1791. On the other hand, the liquidation of Poland's emancipation was regarded by her as inevitable and foremost political task". See idem, Dyplomacja polska..., pp. 619-620. The same author also stated that, while Zubov's coterie wanted to intervene in Poland without other courts' participation, Bezborodko wanted to intervene together with Prussia, because from the very beginning he was the spokesman of the partitioning idea. Let us add, however, that even if Bezborodko initially supported the idea of an armed intervention in the Commonwealth and its partitioning in accordance with Berlin (which meant that an implementation of those ideas would be significantly postponed), he became a definite opponent of those plans, when Platon A. Zubov and his supporters became responsible for their implementation. 
of rescripts for generals Mikhail Kachowski and Mikhail N. Kreczetnikov, who were commanding troops stationed at the borders of the Commonwealth, were accepted, at the same time members of the Council demanded that, before the war was started, the Vienna and Berlin courts should be asked about their opinion (in the latter case there were doubts whether Prussia would, or would not fulfill their treaty obligations towards Poland). Catherine II accepted that decision of the State Council, which meant another delay in the implementation of plans of a group that was supporting Platon A. Zubov. A few days later, however, the empress changed her earlier decision. The news on the death of the Swedish King Gustav III could have caused it. In any case, on April 12/23, orders were sent to Kachowski and Kreczetnikov to be ready to invade the Commonwealth in mid-May 1792. It was also decided to send a text of the declaration of the St. Petersburg court to Jakov Bulhakov, a Russian envoy to Warsaw. The empress's actions were undoubtedly affected by influential court circles. An enormous number of courtiers and officers opposed Bezborodko's peaceful solution to the Polish case, as they were counting on the empress giving them lands taken over from Poland. On April 27, 1792, Polish malcontents swore and signed in St. Petersburg the confederation act, which was later dated in Targowica on May 14, 1792, a date of initially planned invasion of Russian troops on the Commonwealth ${ }^{23}$.

If the St. Petersburg court restrained its troops concentrated on the Commonwealth's borders, it was only because of the empress's uncertainty about a position of the Vienna and Berlin courts. However, very good news were received at St. Petersburg soon. On May 9, 1792, a courier from Berlin reported, that on April 20, the French National Assembly declared war on the successor of Leopold II, Francis, King of Hungary. The news on the outbreak of the Franco-Austrian war greatly pleased supporters of an armed intervention in Poland. If Catherine II still had any doubts on the solution suggested to her, now, in the face of the involvement of both German courts in the West, she easily succumbed to arguments put forward by Platon A. Zubov and his supporters. A few days later,

${ }^{23}$ See C. von Stedingk to Gustav IV Adolf, St. Petersburg April 18/29, 1792, RA, Muscovitica vol. 452; Z. A nu sik, Rzeczpospolita wobec wojny..., pp. 177-178; idem, Misja polska..., p. 128; C. von Stedingk to Samuel N. Casström, St. Petersburg May 21/June 1, 1792, RA, Polonica vol. 229; W. Smoleński, op. cit., pp. 316-317; id e m, Konfederacja targowicka, Kraków 1903, pp. 30-31. 
on May 18, 1792, Yakov Bulhakov declared in Warsaw his court's objection to the Constitution of May 3. On the same day Russian troops crossed the Commonwealth's borders ${ }^{24}$.

Yet, the fate of the Polish-Lithuanian state was not already determined. When the war began, some politicians grouped around Alexander Bezborodko stated, that an armed intervention in the Commonwealth was a serious mistake. Vice-chancellor Ivan A. Ostermann, a friend and formal superior of Bezborodko, said openly that "The Poles have never had a better constitution than the present one, their unity in this matter is the best proof of it, and the confederates, who want to overthrow it, are a bunch of fools". It is also worth noting, that even in the middle of July 1792, when the St. Petersburg court was thinking on the empress's reply to the letter of Stanisław August of June 22, the coterie of Alexander A. Bezborodko once again clashed with Platon A. Zubov's click. Catherine II, tired of a prolonged war and bored with the whole case, under an influence of Bezborodko and his political friends, was ready to cease fire and start negotiations with the Warsaw court. However, the last word once again was that of Zubov, Morkov and Popov. The favorite convinced the empress, that in the name of her honor it was required to support the Targowica Confederation, and thus she should not change anything in hard conditions imposed on the Polish king ${ }^{25}$.

All in all, it must be clearly stated that, before an intervention in the Commonwealth, at the St. Petersburg court there were two political coteries fiercely fighting one with another. Platon A. Zubov, Arkadiy I. Morkov and Vasyl S. Popov were members of the first. Alexander A. Bezborodko, supported by Ivan A. Ostermann and Alexander R. Vorontsov, were representatives of the second one. The group centered around the empress's favorite closely cooperated with Polish malcontents, and aimed at an armed intervention in the Commonwealth, as well as further partitions of its territory. Zubov's group did not exclude the possibility of dividing the Polish-Lithuanian state between Russia and German courts, if they

${ }^{24}$ See Z. Anusik, Rzeczpospolita wobec wojny..., pp. 178-179; W. Smoleński, Ostatni rok Sejmu..., pp. 396-397.

${ }^{25}$ See C. von Stedingk to Charles XI of Sweden, St. Petersburg May 12/23, 1792, RA, Muscovitica vol. 452; Jerzy Michał Potocki to Stanisław August, Stockholm July 20 and 27, 1792, The Science Library of PAU and PAN in Cracow [further on: BPAU], manuscript 1652, p. 208, 211; Z. An u sik, Rzeczpospolita wobec wojny..., pp. 179-180; id e m, Misja polska..., p. 129. 
should oppose to the unilateral partition. On the other hand, Bezborodko and his supporters promoted the idea of a peaceful agreement with Poland, allowing even the possibility to maintain at least part of legal and political solutions proposed by the Great Diet. During the war Bezborodko, who wanted to paralyze actions of his political opponents, was ready to accept the Poles' proposal to cease fire and stop the Russian troops' march on Warsaw. It is worth noting here, that the most important officials from the Collegium of Foreign Affairs were convinced, that it was possible to negotiate with Poland. They were of the opinion, that an armed intervention in the Commonwealth should be agreed upon with German courts. They were also convinced, that Russian troops' invasion on the Polish-Lithuanian state would lead to a long-lasting and costly war. It is supposed, that they wanted to avoid those costs. Platon A. Zubov and his supporters, masterminded by phantasmagorias of Polish malcontents, wanted to immediately strike on the Commonwealth, without waiting for Vienna's and Berlin's decision. They believed that Russian troops would not face any serious resistance, and would force the Poles to a quick surrender. According to their concept, a Russian advantage in the Commonwealth was to be restored by taking over its eastern territories. It seems, that interference in the Commonwealth's internal affairs, initiated with the help of Zubov's group, determined the future partition of Poland. Thanks to the one-sided invasion or the subsequent partition of Poland, the St. Petersburg court could compensate for its expenses incurred during the Turkish war. The partition also allowed to fulfill dreams of Zubov's followers on new pensions, gratifications and lands. It should not surprise anyone too, that when the second partition of Poland took place, Catherine II took pars leonis from the territory of the defeated and humiliated Commonwealth ${ }^{26}$.

${ }^{26}$ See Z. Anusik, Między Warszawa, Sztokholmem i Petersburgiem. Geneza rosyjskiej interwencji $w$ Polsce $w 1792 r$. $w$ świetle korespondencji ambasadora szwedzkiego $w$ Petersburgu Curta von Stedingka, [in:] Przełomy $w$ historii. XVI Powszechny Zjazd Historyków Polskich (Wrocław 15-18 września 1999 roku). Pamiętnik, vol. II, part 1, Toruń 2000, pp. 274-275; ide m, Rzeczpospolita wobec wojny..., pp. 182-183. It is worth mentioning here the account of an eyewitness of events taking place in St. Petersburg in the spring of 1792. After the outbreak of the Polish-Russian war, the Swedish ambassador in the capital of Russia wrote to a Swedish envoy to Warsaw: "It is a moment, when poor Poland experiences a new misfortune from the wicked and unworthily egoistic government, that humiliates the dignity of the nation. I do not doubt that its new constitution is actually much better than the previous one, but it is of a kind that does not please 
As we can see, after the adoption of the Constitution of May 3, there was a real chance of establishing new relations between the Commonwealth and Russia. A decision of the Great Diet's leaders to make Stanisław August a head of foreign policy was certainly right and based on rational assumptions. So there remains the question, how did the king benefit from the prerogatives granted to him. Stanisław August from the very beginning did not allow the possibility of Russian intervention in the Commonwealth's affairs. He wrongly assumed, that it would be sufficient not to provoke the St. Petersburg court, tease all tensions in internal relations, and avoid everything that could give Russia an excuse to intervene. Thus, no steps were taken against Russian agents in Poland. The king, supported by leaders of the Diet, was protecting malcontents, as he was hoping to bring them back to Poland. In the face of such an attitude of the monarch, one should not be surprised that an attempt (rather apparent than real) to start serious negotiations with the St. Petersburg court was a complete failure. What is more, Stanisław August lingered with notifying St. Petersburg of the new constitution. It was only on December 23, 1791, when, under the influence of Adam Kazimierz Czartoryski, who stayed in Dresden and tried to persuade the Saxon Elector to accept the Polish crown, the Diet agreed to make such a notification to the capital of Russia. On the same day the king wrote to Catherine II. Augustyn Deboli handed notifications sent from Warsaw on December 24, to Vice-Chancellor Ivan A. Ostermann on January 3, 1792. Catherine II did not consider it appropriate to give any response to the Commonwealth. It should be also added, that the Polish diplomacy did nothing more in St. Petersburg as regards its activity ${ }^{27}$.

Poland's neighbors, especially Russia, which was accustomed to regard Poland as its vassal. Her Majesty the Empress does not want a new partition of Poland. She only wants to regain her advantage and prevent the resistance (against her dominance) by establishing a hereditary throne... The Council of Her Majesty of Russia was (to the end) divided into parties, from which Her Majesty was made to choose. More experienced ministers were of the opinion that the path of negotiations should be chosen. Yet, younger and more ambitious ones preferred violence and advised a military invasion, which was prompted by Polish emigrants... Only a quick surrender to the Empress's will, or a strong resistance, will (in present circumstances) save Poland”. See C. von Stedingk to S.N. Casström, St. Petersburg May 21/June 1, 1792, RA, Polonica vol. 229.

27 See W. Smoleński, Ostatni rok Sejmu..., p. 79, pp. 238-240, p. 245; Z. Anusik, Rzeczpospolita wobec wojny..., pp. 171-172; idem, Kontrowersje wokót składu..., p. 102, pp. 104-105; M. Kucharski, op. cit., pp. 114-120; 
In that situation one should ask a question, why no direct talks between Warsaw and the Russian court took place? In first weeks after an enactment of the Government Act it seemed that such talks with Russia were necessary. Yet, because of international developments (the king mainly believed in the Prussian-Austrian alliance and Emperor's Leopold II support for the Constitution of May 3), Stanisław August started to believe, that there would be no Russian intervention in Poland at all. Unfortunately, leaders of the Diet started to share that belief, too. Still, Stanisław August's aversion to the negotiations was the most important reason, which prevented talks with the Russian court. It should be underlined at this point, that shortly after an enactment of the Government Act the king exclusively headed foreign affairs, controlled activities of executive authorities, and significantly influenced the legislation. In a word, he became as powerful as never before. Thus, it is obvious that he did not intend to return to his old dependence on St. Petersburg. Also leaders of the Diet were perfectly aware of the fact, that the public opinion was definitely in an anti-Russian mood, which was the main reason why they tried to make Stanisław August responsible for carrying out difficult and unpopular Russian negotiations. All in all, it was mainly Stanisław August, who neglected contacts with the St. Petersburg court. Still, leaders of the Great Diet were to be blamed for it too, as they began to share the king's conviction, that an Austrian-Prussian alliance was a sufficient guarantee for the inviolability of the Commonwealth's borders and constitution ${ }^{28}$.

J. Łojek, Geneza i obalenie..., pp. 219-221. Jerzy Michalski’s statement is unacceptable, on the other hand, as he argues that "Stanisław August, to whom the Constitution of May 3 formally returned the power and influence on foreign policy, and who entrusted it with his trustworthy Vice-Chancellor Chreptowicz, the supporter of Russia, wished to seek agreement with the St. Petersburg court. He was afraid, however, that he would be accused of being disloyal, or even reluctant to returning to the situation before 1788. Therefore, he abandoned the thought of writing to Catherine II and notifying her of the Constitution of May 3". See id e m, Dyplomacja polska..., p. 646.

28 The king's assertion that Russia would not intervene in the Commonwealth was confirmed in his correspondence with Polish diplomats accredited to foreign courts. For example, in January 1792, Stanisław August wrote to Jerzy Potocki in Stockholm: "If Russia attacks us, the fact which I do not believe in, the self-interest of our neighbors is to defend us". In the beginning of February the king wrote to Potocki that sejmiks planned for the second half of the month would certainly thwart plans of Russia and emigrants opposed to the Constitution of May 3. A few weeks later he wrote again: "There are various reasons why Moscow will not fight with us". At the beginning of April, Stanisław August wrote to Jerzy Potocki: 
At this point it should be noted, that after the adoption of the Constitution of May 3, the vast majority of deputies and senators were kept in the dark as regards the foreign policy of the king and the Diet's leaders. The Diet was rarely informed on an international situation, and its members were rather poorly informed on those issues. Actions of opponents of the Government Act were the main object of interest of the Chamber of Deputies. On May 10, 1791, at the request of the Crown Field Notary, Kazimierz Rzewuski, a law ordering senators and deputies holding military offices but absent in Warsaw to respond before the Military Commission was passed unanimously. Such a resolution was to force them to make an oath to the constitution. Needless to say, it was primarily aimed at the leading opponents of the Constitution of May 3, the Artillery General, Stanisław Szczęsny Potocki, and the Crown Field Hetman, Seweryn Rzewuski. Later on, the Kalisz deputy, Józef Miaskowski, referred directly to that resolution and on June 22, 1791, he submitted the request that officers serving the Commonwealth, but staying abroad, should return to Poland and make an oath to the

\footnotetext{
"After April 16, we will be looking for defensive arrangements, which will be easier as Berlin and Vienna have recently made an agreement". However, at the end of that month, in the next letter of the king to the envoy to Stockholm, there was a statement: "We are seriously preparing here to a defense but, as far as I am concerned, Moscow will not start war against us”. See Stanisław August to J. Potocki, Warsaw January 21, February 1 and 22, April 4, 18 and 25, BPAU, manuscript 1653, p. 9-10,13,15, pp. 17-18. Ignacy Potocki's letter to the king of mid-March 1792, confirms that the Diet leaders shared the royal belief that the Austrian-Prussian alliance was a sufficient guarantee for the security of the Commonwealth. The Great Lithuanian Marshal wrote: "The news of the death of the emperor was the reason, why I made various remarks on the further political relation between us and the Austrian house, which honest interest now requires even more bounds with the Brandenburg and Saxon houses in the German Reich. It would be unwise to conclude, that the emperor's death would change the ultimate system, and that we should fear bad consequences for us". See I. Potocki to Stanisław August, Warsaw March 16, 1792, as quoted in W. Smoleński, Ostatni rok Sejmu..., p. 318. See also ibidem, p. 238, pp. 240-241; Z. Anusik, Misja polska..., p. 126; i d e m, Kontrowersje wokół składu..., pp. 103-104; id e m, Rzeczpospolita wobec wojny..., pp. 172-173; B. Leśs nodorski, op. cit., p. 315. It is worth mentioning here, that in March 1792, in the face of an apparent collapse of an alliance with Prussia, Warsaw made an attempt to sign a formal alliance with the Vienna court. But that initiative was far too late, and at that time it could not count on any support from political circles of the Austrian capital. See D. Naw rot, Próba reorientacji polskiej polityki zagranicznej w marcu 1792 r., [in:] Dyplomacja. Polityka. Prawo. Ksiega pamiątkowa ofiarowana Profesorowi Henrykowi Kocójowi $w$ siedemdziesiąta rocznice urodzin, ed. I. Panic, Katowice 2001, pp. 64-73.
} 
constitution. Marshal Stanisław Małachowski replied, that it had to be decided upon by the executive power, but at the request of the estates he could ask the king of an opinion. At that moment the castellan of Przemyśl, prince Antoni Czetwertyński, protested against being compelled to make an oath to the new constitution. When he began to criticize the Government Act, he provoked a turbulent discussion, which distracted everybody's attention from Miaskowski's request. The king was satisfied with such a solution, because he did not want to further exacerbate his relations with Szczęsny Potocki by executing the law of May $10^{29}$.

Other opponents of the Constitution of May 3 were treated according to Stanisław August's policy as well. On June 7, 1791, the Cracow deputy, Stanisław Sołtyk, warned against traitors, who were starting unnecessary disputes and delaying legislative activity. Therefore, supported by the Chamber of Deputies, he asked the king to do whatever he could to trace those, who had been paid for by the enemy. The king promised the deputies, that he would do his best in that regard, but at the same time he casted doubt on "the existence of tools serving to the enemies". Although the public opinion was unequivocal and demanded to prosecute and punish traitors and enemies of the Government Act, the executive power did nothing about it. The Police Commission of the Two Nations, created on July 4, 1791, did not take any steps against malcontents. No one was brought before the court, no charges were filed. The opponents of the Constitution of May 3 were morally influenced, rather than repressed. For obvious reasons supporters of the St. Petersburg court could have counted on the impunity, too ${ }^{30}$.

On June 28, 1791, deputies had a holiday break, which lasted until September 15. Shortly after that date the issue of leading malcontents was discussed once again. On the evening of October 23, the courier brought to Warsaw news on the death of prince Grigory A. Potemkin. Consequently, during the session of October 24, 1791, Michał Zabiełło, the Livonia deputy, referred to the law of May 10, and demanded Szczęsny Potocki and Seweryn Rzewuski

${ }^{29}$ See W. Smoleński, Ostatni rok Sejmu..., pp. 152-153; Zlecenie uum: seymowemu y konfederacyi o. n. marszałkom, VL, vol. IX, p. 227; Ł. Kądziela, Rzewuski Kazimierz, [in:] PSB, vol. XXXIV, p. 123; M. Złomska, Miaskowski Józef, [in:] PSB, vol. XX, Wrocław 1975, p. 541.

${ }_{30}$ See W. Smoleński, Ostatni rok Sejmu..., p. 69; M. Czeppe, E. Orman-Michta, Sołtyk Stanisław, [in:] PSB, vol. XL, Warszawa-Kraków 2000-2001, p. 426. 
to make an oath to the Constitution of May 3, and explain their stay in Jassy. Konstanty Jelski, the Starodub deputy, made a request, that those officials who without permission of the Commonwealth were staying abroad, should be deprived of their salaries. Prince Adam Kazimierz Czartoryski suggested, that the case of both malcontents should be settled by the court, and demanded Zabiełla's proposal to be dealt with together with military issues. After a long discussion, it was finally agreed upon, that both malcontents should be summoned to the country. In line with the Diet's resolution, on October 25, the king ordered the Crown Field Hetman, while the Military Commission ordered the Artillery General, to fulfill their duties within three months starting from October 27, 1791. On December 5, the king and the Military Commission once again sent their orders to Rzewuski and Potocki. The next day, there was another dispute in the Chamber of Deputies. Tadeusz Kościałkowski, the Ukmerge deputy, in strong words condemned the schemes of the malcontents in Jassy. Jan Nepomucen Zboiński, the Dobrzyń deputy, advised not to accept any manifestations and protests against the Diet or the constitution in the public record. He also stated that, both the protestors and those who admit such documents to records, should be punished and announced the destroyers of the public order. The castellan of Przemyśl, prince Antoni Czetwertyński, and Stanisław Hulewicz, the Volyn deputy, defended malcontents during that turbulent discussion. Kazimierz Nestor Sapieha, the Marshal of the Lithuanian Confederation, swore on his uncle's behalf, the Crown Grand Hetman, Franciszek Ksawery Branicki. The king tried to disallow an adoption of a resolution against opponents of the Government Act, but finally the Diet passed a "declaration on manifests" 31.

On January 2, 1792, the Military Commission issued the third and last order to Szczęsny Potocki. The king assumed, that if the Artillery General disobeyed, the Diet would no longer indulge him. However, even then Stanisław August deluded himself, that he

${ }^{31}$ See W. Smoleński, Ostatni rok Sejmu..., pp. 187-191, 197-203; J. Łojek, Geneza i obalenie..., pp. 228-229; E. Rostworowski, Jelski Konstanty, [in:] PSB, vol. XI, Wrocław-Warszawa-Kraków 1964-1965, p. 154; Głos Jaśnie Wielmożnego Jegomości Tadeusza Kościałkowskiego z Zyndranów, starosty Czotyrskiego, posła Wiłkomierskiego na sesyi seymowey dnia 6 Grudnia 1791 r. miany, Warszawa [1791]; B. Krakow ski, Kościałkowski Tadeusz, [in:] PSB, vol. XIV, Wrocław-Warszawa-Kraków 1967-1968, p. 397; Deklaracya względem manifestów, VL, vol. IX, p. 367. 
could persuade malcontents to recognize the new constitution. On the same day he wrote a letter to Szczesny and sent it to Jassy through Stanisław Kostka Potocki. Yet, when the latter arrived at its destination (on January 13), the Artillery General had already negatively responded (on January 10) to the last order of the Military Commission. Stanisław Kostka Potocki's mission did not bring the results desired by the king. In the meantime, deputies had also lost their patience. On January 26, 1792, Michał Zabiełło reminded that Potocki's and Rzewuski's deadline to make an oath to the constitution was near, and demanded that reports on the matter should be submitted to the Guardians of the Laws and the Military Commission. On January 27, Marshal Stanisław Małachowski proposed to postpone a parliamentary debate, but Zabiełło repeated his request. Orders sent to malcontents and their replies were read. The Livonia deputy, Julian Ursyn Niemcewicz, ardently accused both bold dignitaries, and demanded to deprive Szczęsny Potocki of the title of the Artillery General, and both of them of Lower Crown Maces. Primate Michał Poniatowski spoke in the defense of both malcontents. They were also defended by Marshal Kazimierz Nestor Sapieha, the Volyn deputy, Jan Zagórski, the Ukmerge deputy, Józef Dominik Kossakowski, and castellan of Przemyśl, prince Antoni Czetwertyński. The king advised to deal with that matter after the session. Niemcewicz's request was supported by deputies of Ukmerge, Tadeusz Kościałkowski, Liwsk, Pius Kiciński, Cracow, Stanisław Sołtyk, and Braslau, Tomasz Wawrzecki. They were supported by the majority of the Diet. In the face of an inevitable defeat, senators and deputies who were against the punishment of malcontents left, and those who stayed, adopted Niemcewicz's bill. The king was not certainly satisfied, as it was against his political line, but the public opinion received the Diet's resolution with great satisfaction. On January 28, 1792, due to the February deputational and administrative sejmiks, the Diet's sessions were postponed until March $15^{32}$.

On February 14, 1792, deputational and administrative sejmiks took place. They were a kind of the referendum, in which the nobil-

${ }^{32}$ See W. S moleń s ki, Ostatni rok Sejmu..., pp. 210-228, 230-231; Stanisław August to Franciszek Bukaty, Warsaw January 7 and 28, 1792, W. Kalinka, Ostatnie lata..., part 2, p. 208, pp. 210-211; B. G rochuls ka, Potocki Stanisław Kostka, [in:] PSB, vol. XXVIII, p. 162; I. Ho mola, Kossakowski Józef Dominik, [in:] PSB, vol. XIV, p. 275; Deklaracya względem osób woyskowych nieprzysięgłych $i$ zniesienia buław polnych, VL, vol. IX, p. 403. 
ity had the opportunity to express their views on the Constitution of May 3 for the first time. The results were a great victory of the Government Act's supporters. Approximately 90\% of the assemblies accepted the Constitution of May 3. A political opposition, with only $10 \%$ of sejmiks, pushed away the Government Act. Although in reality more noblemen were dissatisfied with the May 3 assassination $(17 \%$ of sejmiks adopted only acknowledgements of the constitution), the fact is that almost $75 \%$ of sejmiks were won by the constitutional camp. Thus, the basic purpose of the February sejmiks was achieved. The provincial gentry accepted the Government Act. Successful results of the referendum made the king hope, that Moscow would refrain from hostile steps, and the Elector of Saxony would finally agree to accept the Polish crown ${ }^{33}$.

Stanisław August's hopes turned out to be unfounded. No reply of St. Petersburg to the notification of the Constitution of May 3 effectively blocked negotiations with the Dresden court, which as a condition of sine qua non demanded Catherine II's formal consent to the elector accepting the Polish crown. Augustyn Deboli sent even more disturbing news from the capital of Russia. Nevertheless, the king still delayed his actions, and only at the end of March he began to think of any preparations for defense. At the session on April 16, 1792, deputies heard a report on negotiations with the Saxon Elector, and were informed that Russia had told its neighbors that it had not accepted the Constitution of May 3, and wished to keep the form of government guaranteed in 1775. The Minister of Foreign Affairs in the Guardians of the Laws also added, that the St. Petersburg court intended to march with its troops (returning from Moldova after the war with Turkey) through the Commonwealth's territory. Yet, when a draft authorizing the king to strengthen the country's defense was introduced, deputies from Cracow, August Otwinowski, Volyn, Ignacy Kuszczki and Trakai, Ignacy Siwicki, demanded deliberation. Thanks to the strong support of the project by Adam Szydłowski from Mielnik, Kazimierz Nestor Sapieha and the king himself, the draft was accepted unanimously. At that time, there was also adopted a resolution, which made the king a head of the army, and authorized him to invite several generals (one, two or three) from the foreign army to the Polish artillery, as well as experienced officers to engineering corps. The

${ }^{33}$ See W. Szczygielski, Referendum trzeciomajowe. Sejmiki lutowe 1792 roku, Łódź 1994, p. 397; W. S moleńs ki, Ostatni rok Sejmu..., pp. 298-299. 
Military Commission was instructed to take a loan worth 30 million zlotys, which was to be secured by a fund raised from the planned sale of county offices. At the request of Stanisław Soltyk from Cracow, that resolution was to be announced to Dresden, Vienna and Berlin. On April 21, 1792, the king read in the Chamber of Deputies extracts from Deboli's recent messages from St. Petersburg. However, he omitted names of Szczęsny Potocki and Seweryn Rzewuski. On that occasion he stated, that General-Lieutenant Szymon Kossakowski had assured him in his letters, that if the war was to break out, he would resign from the Russian service. He hoped to avoid the crisis peacefully, but was still encouraging to carry out armaments. What is more, on that day two acts were unanimously passed. The first authorized the king to occupy 100 thousand soldiers more in the army. The second, allowed 20 foreign officers to serve in the Polish army ${ }^{34}$.

Immediately after a solemn celebration of the anniversary of the adoption of the Constitution of May 3, the Diet undertook further efforts to strengthen the defense of the country. On May 7, 1792, at the request of Ignacy Potocki, who was replacing the absent Minister of War, two Tatar regiments, two Cossack regiments and four battalions of volunteers were unanimously approved on. On May 14, a decision was made to incorporate all magnates' militias into a regular army. Landowners were allowed to maintain an armed force of no more than 40 people. Donations for defense, and voluntary admission to the army were encouraged. At the session on May 18, a draft describing the Military Commission was passed. Before the vote, Jakov Bulhakov handed Joachim Chreptowicz a declaration of the Russian court, explaining the reasons for the entry of the empress's army within the Commonwealth's

${ }^{34}$ See W. S moleńs ki, Ostatni rok Sejmu..., pp. 248-249, 347-350, 354-356; Deklaracya doczesna and Umieszczenie w woysku Rzeczypospolitey dwudziestu officyerów z służby zagraniczney, VL, vol. IX, pp. 423-424. It may be worth mentioning here, that in spite of preparations for the defense of the country, Stanisław August hoped that there would be no war. Such an opinion he wrote in an above-quoted letter to the Commonwealth's envoy to Stockholm. See Stanisław August to J. Potocki, Warsaw April 25, 1792, BPAU, manuscript 1653, p. 15; Z. Anusik, Misja polska..., pp. 126-127. The king similarly wrote in his letter to Franciszek Bukaty in London: "Yesterday, I had the news from Vienna (as well as from Berlin), that both of those courts believe that Moscow will not start hostilities against Poland, because it has issued them about us, and vice versa, so we may have to wait in uncertainty a few more weeks". See Stanisław August to F. Bukaty, Warsaw April 25, 1792, W. Kalinka, Ostatnie lata..., part 2, p. 216. 
borders. The news spread across Warsaw immediately, causing consternation and panic. On May 19, 1792, leaders of the Diet met at Vice-Chancellor Hugo Kołłataj. They decided to read the Russian declaration during the forthcoming session with the participation of arbitrators. It was also decided to ask the Prussian, Austrian and Saxon envoys, whether Poland could count on their courts' help. At the same meeting it was agreed upon that Stanisław August would become a head of the army. On Monday, May 21, the declaration of the St. Petersburg court was read in the Diet. Then, the king spoke. He announced, that he would ask for help friendly neighbors, Prussia, Austria and Saxony. Still, he also stated, that he would not neglect anything that could open the way to start negotiations with the empress, and dispel the crisis with a pen, rather than a weapon. At the end of his speech, he asked deputies to quickly end all cases that had been already started. On May 22, the Diet entrusted Stanisław August with the command of the army, and adopted a draft of a new military policy ${ }^{35}$.

At the session of May 24, 1792, Stanisław Olędzki, the Samogitia deputy, asked the king to reveal the names of malcontents, who were conspiring in St. Petersburg against the Commonwealth. The Crown Field Notary from Podole, Kazimierz Rzewuski, demanded to reveal names of deputies and senators, who maintained relations with the empress's court. But the king did not want to do it. Konstanty Jelski, the Starodub deputy, suggested to force Szczęsny Potocki, Seweryn Potocki and several other malcontents, who stayed in the capital of Russia, to stand before a parliamentary court within three weeks. Stanisław August advised to restrain the punishment. Immediately after the king's speech, a resolution ordering Poles remaining in the Russian service to return to the country was passed unanimously. Those Poles, who were serving in the Russian army were declared enemies of the homeland. As such enemies were also to be treated those, who were the first to conspire against the Diet and the Commonwealth, unless they gave up the conspiracy within six weeks. Finally, all participants of hostile conspiracies were threatened with a loss of civil rights and honor, as well as the death penalty. An extraordinary court to

35 See W. Smoleń s ki, Ostatni rok Sejmu..., pp. 393-400; Uformowanie dwóch pułków Tatarskich, dwóch Kozackich i czterech batalionów ochotników, VL, vol. IX, pp. 438-439; Wyprawy obronne, ibidem, pp. 443-445; Głos Jego Królewskiej Mości dnia 21 maja roku 1792, [Warszawa 1792]. 
penalize traitors was set up at the same session. On May 24, the tax increase was agreed upon. On May 25, a fund of 1.5 million zlotys was guaranteed for soldiers, who would stand out in combat, while widows and orphans of those killed in a battle were provided half of their wages. On the same day, the king bravely spoke to the army. On May 29, 1792, at the morning session, the Diet was presented with an unfortunate ("in content and form inapt") response to the Russian declaration. On the same day, the Diet adopted Grzegorz Piramowicz's and Hugo Kołłątaj's proclamation to the nation, and after a heated discussion it decided unanimously, that there would be no sessions during the war ${ }^{36}$.

When the Diet suspended its sessions, Stanisław August was fully responsible of the state's fate. The king, similarly to leaders of the patriotic party, was more inclined to start negotiations with the St. Petersburg court, rather than to carry out vigorous military actions. Although he did not believe in the effectiveness of such an action, he asked German courts for help, especially as he wanted to keep up appearances. On May 22, prince Adam Kazimierz Czartoryski went to Vienna to ask the Austrian ruler for help ${ }^{37}$. On May 25, Joachim Chreptowicz handed Prussian envoy to Warsaw, Girolamo Lucchesini, a note with the request to help the Commonwealth under the terms of the alliance of March 29, 1790. A few days later (on May 31), Ignacy Potocki left for Berlin to talk to the Prussian king ${ }^{38}$. To the amazement of bystanders, when the war with Rus-

${ }^{36}$ W. Smoleński, Ostatni rok Sejmu..., pp. 406-413; M. Złomska, Olędzki (Olendzki) Stanisław, [in:] PSB, vol. XXIII, Wrocław 1978, p. 797; Kommenda I.K. Mości nad woyskiem Rzeczypospolitey, VL, vol. IX, p. 447; Deklaracya wzgledem stanu teraźnieyszego Rzeczypospolitey, ibidem, pp. 449-450; Pobór generalny, ibidem, p. 450; Nadgroda dziet walecznych, ibidem; Sad seymowy extraordynaryiny, ibidem, p. 452; Kommissya woyskowa oboyga narodów, ibidem, pp. 457-468; Limita seymu, ibidem, pp. 469-470.

37 Only an optimist could have believed that the Vienna court, entangled in a war with revolutionary France from April 20, 1792, would want, and would be able to help the Commonwealth. Both the king and leaders of the Diet perfectly knew that prince Adam Czartoryski's mission was doomed to failure.

38 The Prussian King, Frederick William II, decided on January 9, 1792, not to defend the Commonwealth. At the beginning of February, when in Vienna the signing of a preliminary treaty between Austria and Prussia was being finalized, Prussian diplomacy demanded to change in the final version of the treaty the paragraph concerning the Polish-Lithuanian state. Instead of the statement, that allied states would jointly defend (the present) Polish constitution, there was introduced a record that the free constitution of Poland would be supported, which gave the opportunity for a free interpretation. Later in the same month, Prus- 
sia started, no one asked Russian ambassador, Yakov Bulhakov, to leave Warsaw, because there was a plan to begin secret talks with him ${ }^{39}$. In the meantime, the king was deliberating with leaders

sian diplomacy in St. Petersburg tried to find out, what was Russia's position on the idea of another partition of the Commonwealth. See S. Askenazy, op. cit., pp. 173-175, 184-186; W. Smoleńs ki, Ostatni rok Sejmu..., p. 253. Let us add here, that S. Askenazy did not have the slightest doubt that Ignacy Potocki was fully aware of the hopelessness of his efforts to induce Frederick William II to fulfill his ally obligations. See idem, op. cit., pp. 196-197. According to W. Smoleński: "The Poles did not know about the change of the position of the Berlin court", and Ignacy Potocki, talking on the Berlin mission, "was not clearly aware of the situation". See id e m, op. cit., pp. 253-254, p. 425. However, this argument is completely unfounded, since at least from the beginning of May 1792 (in my opinion much earlier), Warsaw knew that Prussia would not treat Catherine II's intervention as casus foederis. See J. Michalski, Dyplomacja polska..., p. 648; Z. A nu sik, Kontrowersje wokół składu..., p. 114. It is also worth noting, that Stanisław August Poniatowski was aware of Prussia's change of opinion. On April 11, 1792, he wrote to Franciszek Bukaty in London: "The open war probably will not break out. But should Moscow start a war, the Prussian king, although he would not be happy, would have to defend us, because according to the alliance he is obliged to defend our independency". However, on May 9, the king wrote to the above-mentioned addressee about Frederick William II's conduct: "Well, he wants to scare us, showing that he is leaving us completely, even betraying, to frighten us so much, to make us kneel in front of Moscow, hoping that if it force us to leave the hereditary throne, it will allow us to preserve other laws of May 3". See Stanisław August to F. Bukaty, Warsaw April 11 and May 9, 1792, W. Kalinka, Ostatnie lata..., part 2, pp. 214-215, p. 217. The king expressed his conviction about Prussia's behavior even more clearly in his letter to the Polish ambassador in Stockholm. He wrote in it that: "he realized that the Russian declaration [of May 18, 1792 - author's note], made such an impression on Prussia that it would attack not only the act of May 3, but also the entire work of the Diet". See Stanisław August to J. Potocki, Warsaw May 23, 1792, BPAU, manuscript 1653, p. 23. The Polish envoy to Berlin, prince Stanisław Paweł Jabłonowski, also knew that Prussia will not help Poland. Still, already in May 1792, the Diet was not aware of the political isolation of the Commonwealth. The reason was that Jabłonowski's warnings to the king and Chreptowicz were kept secret. See M. Kucharski, op. cit., pp. 125128; Z. Anusik, Rzeczpospolita wobec wojny..., p. 183.

${ }^{39}$ Ignacy Potocki strongly criticized the king's and Joachim Chreptowicz's actions taken in the early days of the conflict with Russia: "It is obvious that our Minister of Foreign Affairs only intends to reconcile the king with Moscow as soon as possible. And although sometimes he eagerly says: "We have to defend, we have to be brave", when it comes to special steps and deeds, he resigns of them, or weakens them. From May 18, no courier was sent to Berlin or Vienna, Dresden, Istanbul. Under less important circumstances we were more attentive and hasty. There are reasons why defense is weak, but there is no justification for a tardiness of negotiations. Honestly, as a friend, I warn you, that we will soon need to humbly beg the empress of Moscow". See I. Potocki to Stanisław Małachowski, Warsaw May 28, 1792, J. Łojek, Geneza i obalenie..., Appendix X, p. 458. The 
of the Diet. During their meetings, they were not debating on how to effectively lead the war, but how to begin negotiations with Catherine II on the ceasefire, and save at least some of the Constitution of May 3's paragraphs ${ }^{40}$. Finally, after a preliminary agreement on the content of his speech, which was agreed upon with leaders of the

Polish envoy to Stockholm was of the similar opinion about actions undertaken by the Polish diplomacy, as he wrote: "It is unbelievable what these people are doing. They do not send away anyone, they do not send credentials, and Stackelberg is asking magno motu for support, while Chreptowicz does not give me any orders". See J. Potocki to I. Potocki, Stockholm May 25, 1792, The Central Archives of Historical Records in Warsaw [further on: AGAD], The Public Archives of Potocki's Family [further on: APP] No. 227, pp. 450-451. Let us explain on this occasion, that Potocki needed new credentials, as the old ones had expired after Gustav III's death on March 29, 1792. Catherine II's ambassador in Stockholm (Otto Magnus von Stackelberg) was asking for the Swedish support against the Commonwealth under the Drottningholm treaty signed by a deceased king of Sweden and the empress in October 1791. Yet, another Jerzy Potocki's letter to the Great Lithuanian Marshal was even more significant: "As I see, they are fighting, but they take wrong steps, because I do not know why they allowed Bulhakov to stay. This idea is so difficult to explain, that everybody, me included, is laughing at this policy, and I see that it is going nowhere. In a word, according to my opinion, this is a great shame and a truly incomprehensible thing". See J. Potocki to I. Potocki, Stockholm June 15, 1792, AGAD, APP No. 227, p. 453. Let us add, that Potocki comments here what was a reaction in the capital of Sweden to a decision of Polish authorities that permitted the Russian envoy to stay in Warsaw, despite the fact that the St. Petersburg court started war against the Commonwealth.

${ }^{40}$ It is worth mentioning here the opinion of Emanuel Rostworowski, who wrote that leaders of the patriotic party naively thought they had an excellent political argument: an offer of a Polish crown to Catherine II's grandson, Grand Duke Konstantin. The author quoted prince Adam Kazimierz Czartoryski's statement of December 1791 "in the case of the Elector of Saxony's refusal [to a crown - author's note], the wisest step of Poland will be to declare to the empress: keep the Constitution and we will agree to give the throne to your grandson". See E. Rostwo rowski, Ostatni król..., p. 288. Still, in my opinion, Czartoryski's statement should be interpreted as some kind of pressure on Frederick Augustus III, as well as a step prompting Stanisław August to start negotiations with Russia and make public opinion aware of the need of such talks with the empress. It should be also emphasized, that Czartoryski's suggestion was not approved by the king, who wanted to give a crown to one of his nephews. Only in the face of the war with Russia leaders of the patriotic party (this time with full approval of the king) returned to the concept of giving the crown to Catherine II's grandson. Although I agree with E. Rostworowski that Polish politicians overestimated the attractiveness of the Polish crown on the European dynasty market, it is difficult to accept without hesitation his view, that the Polish-Russian war of 1792 was only the Polish demonstration, which was to facilitate negotiations on giving the crown to Grand Duke Konstantin. See id e m, Maj 1791 - maj 1792. Rok monarchii konstytucyjnej, Warszawa 1985, p. 35; and id e m, Ostatni król..., pp. 288-289. See also Z. Anusik, Kontrowersje wokół składu..., p. 106, 115. 
patriotic party and the Russian envoy, who made some changes to the original text, on June 22, 1792, Stanisław August wrote a letter to the empress, proposing a crown to her minor grandchild, Grand Duke Konstantin, and offering the Polish-Russian alliance treaty with a mutually advantageous trade agreement at the same time. Stanisław August also asked Catherine II to stop war as soon as possible ${ }^{41}$. The Russian response, dated in St. Petersburg July 13, 1792 , arrived after a month of nervous anticipation. The empress repeated all arguments of the Declaration of May 18, and demanded the king to immediately join the Targowica Confederation ${ }^{42}$.

Although the majority of Polish historians argue that proposals contained in Stanisław August's letter were ridiculous, belated and unacceptable for the St. Petersburg court, in Tsarskoye Selo there were held long and heated discussions between the empress's advisers, before negative response of Catherine II was finally given to Stanisław August's letter. The Swedish ambassador in St. Petersburg, Curt von Stedingk, in a message of July 14, 1792, clearly wrote about a great impression that Stanisław August's letter had made on Catherine II. In his opinion, the empress was very pleased with the way it was written. The ambassador also repeated the opinion, which prevailed in the Russian capital, and stated that Catherine II, impatient with prolonged war and bored with the whole case, was prepared to listen to her old advisers (Bezborodko, Ostermann, Vorontsov), and waive some of the claims against Poland. Yet, Platon A. Zubov, supported by Morkov and Popov, told the empress, that her honor required her to protect the party she chose, and did not change anything in hard conditions that had been imposed on the Polish king. On that occasion, Stedingk expressed his sympathy for Stanisław August's fate, an unfortunate monarch forced to negotiate with the rebellious subjects. He also lamented the fate of the Commonwealth, which was to get under the Russian yoke again. He also did not exclude future partitions, as he anticipated that the Prussian king would certainly want to participate in that new catastrophe, that had just hanged over Poland ${ }^{43}$. It is worth mentioning here, that Jerzy Potocki in Stockholm also knew

${ }^{41}$ For more information see J. Łojek, Geneza i obalenie..., pp. 350-366.

42 See ibidem, pp. 406-408.

${ }^{43}$ See C. von Stedingk to Gustav IV Adolf, St. Petersburg July 3/14, 1792, apostille, RA, Muscovitica vol. 453. See also Z. Anusik, Rzeczpospolita wobec wojny..., pp. 181-182. 
about two fighting coteries in the empress's closest circles. As early as July 20, 1792, he wrote in a letter to Stanisław August as follows: "The empress accepted the ceasefire at first, but Morkov, the intriguer, made her change that decision". A week later Potocki wrote again: "When the letter of Your Majesty was given to the empress, she firstly was inclined to it, Ostermann and Bezborodko were of that opinion, but Zubov, Morkov and Popov totally changed her mind" 44 .

Limited armed forces at the Commonwealth's disposal and, above all, a lack of faith in victory among people governing the state, were main reasons of an ultimate defeat of the Poles in the war with Russia $^{45}$. On July 24, 1792, Stanisław August decided to join the Targowica Confederation. That step, as it seems, could have been (after some hesitation) approved by leaders of the patriotic party, although at the meeting of the enlarged Guardians of the Laws, from the Great Diet's leaders only Hugo Kołłataj was openly in favor of the king's accession to Targowica and his negotiations with its authorities. Later also other leaders of the Diet decided that in the face of a lost war only the king, thanks to his old acquaintance with Catherine II, would be able to save some of the Great Diet's reforms, and cast away the specter of a new partition that was threatening the Commonwealth ${ }^{46}$. It quickly turned out, however, that those hopes were completely unfounded, and people associated with the reform camp almost immediately realized, what political mistakes had been committed within couple of months after the adoption of the Constitution of May 3. Already at the end of July 1792, Jerzy Michał Potocki, embittered by reports from Poland, wrote to his

${ }^{44}$ J. Potocki to Stanisław August, Stockholm July 20 and 27, 1792, BPAU, manuscript 1652, p. 208, 211. See also Z. Anusik, Misja polska..., p. 129; and id e m, Rzeczpospolita wobec wojny..., p. 182.

${ }^{45}$ It is worth to underline, that in the face of Russian intervention, a relatively uniform political front of leaders of the patriotic party had collapsed. Hugo Kołłataj from the beginning (like Stanisław August) did not believe in the effectiveness of resistance, and advised to seek an agreement with the St. Petersburg court by offering the Polish crown to the grandson of the empress. Ignacy and Stanisław Kostka Potocki also did not rule out an agreement with Russia, but they wanted to negotiate (if possible) on equal terms with the support of the strong Polish army. Stanisław Małachowski believed in the Commonwealth's good military preparation and counted on a final success in the battle with the empress's interventionist troops. See Z. Anusik, Kontrowersje wokót składu..., p. 116.

${ }^{46}$ See J. Łojek, Geneza i obalenie..., pp. 408-417; Z. A nu sik, Rzeczpospolita wobec wojny..., p. 183. 
elder brother, the Great Lithuanian Marshal Ignacy Potocki, with a sharp critique of the Commonwealth's recent foreign policy: "As Prussia proved treacherous, one should not have trusted it in the past, when it was deceiving Sweden, one should not have given it a chance to lead their nose. One should have given them Gdańsk, when signing a treaty, thus avoiding half measures. After the Constitution of May 3, one should have sent an ambassador to Russia, rather than playing romantically"47. A week later Jerzy Potocki wrote again to Ignacy: "I sincerely confess you my brother, we are lost by our politics... things would be better, if we had openly punished traitors" ${ }^{\prime 8}$. It is worth underlining, that Władysław Smoleński came to similar conclusions. In his view, the Diet did not take any steps to safeguard its work from internal conspiracies and actions of external enemies. The emigrants were treated indulgently. The king was not helping, but doing more harm to the case. No steps were taken to prepare the country for a possible war. Defensive measures of April 16, 1792, were introduced decidedly too late ${ }^{49}$. "Stanisław August repeatedly deluded himself [as regards negotiations with Russia - author's note], and having almost a discretionary power he could have been going astray at his will. The Diet seriously sinned, as it believed in the speech he gave at the meeting on May 22, 1792: "Have trust! When there will be a need of my life, I will not spare it»; it was unwise to end deliberations and put the fate of the country into the hands of a man, who had his merits, but did not grow up to the role of a leader"50.

Within a few months after the king's accession to the Targowica Confederation, Stanisław August and the Diet leaders found themselves on different paths. The view of Andrzej Zahorski seems to be fully justified, as he stated that at the very time: "The king, by joining the Targowica Confederation, tried to save the country from a new division and return under the Russian protectorate. That solution was approved of by leaders of the Diet, but it turned out, that the Poles had gone astray. Russia quickly realized, that Targo-

47 J. Potocki to I. Potocki, Stockholm July 20, 1792, AGAD, APP No. 227, p. 463. See also Z. Anusik, Misja polska..., p. 130; and idem, Kontrowersje wokół składu..., p. 108.

48 J. Potocki to I. Potocki, Stockholm July 27, 1792, AGAD, APP No. 227, p. 464. See also Z. Anusik, Misja polska..., p. 130; and idem, Kontrowersje wokół składu..., p. 108.

49 See W. S moleńs ki, Ostatni rok Sejmu..., pp. 420-423.

50 Ibidem, p. 427. 
wica was pointless, and that in the face of widespread hatred of it, as well as the universal demand for full independence, a Russian reign over Poland could not be maintained through confederates. In this situation, Catherine decides on the second partition of Poland" ${ }^{2}$.

In the face of an inevitable partition, while preparing an anti-Russian national rebel, leaders of the patriotic party, who found shelter in exile in Saxony, began to work on a famous "On the establishment and collapse of the Polish Constitution of May 3". Ignacy and Stanisław Kostka Potocki, Franciszek Salezy Dmochowski, and Hugo Kołłątaj denied their participation in an appointment of declared Russian supporters to the Guardians of the Laws, making Stanisław August responsible for the collapse of the Diet's work. Former patriotic party's leaders pointed out to the king, that he was too submissive when delegating people to the state's supreme offices, as they wrote: "It is a feature of weak minds not to be able to utterly abandon old habits. Their timid policy always seeks to preserve friendship and support in, both one and the other side, so that in the event appropriate to them, the variability could easily find access. Thus, they caress vice, though they are for virtue, while joined in a crime, they sigh to the virtue" 52 . As regards the king's foreign policy after the adoption of the Constitution of May 3, authors of the above-quoted work accused Stanisław August that "he put small procedures, dark intrigues, small work of offices, shy caution, vile indulgence over brave measures, which could have saved the nation that was destroying the yoke of foreign violence" 53 . Here the question arises: why former leaders of the Great Diet did not mention, that the king had lost the opportunity to negotiate with the St. Petersburg court and reverse the threat of Russian intervention in the internal affairs of the Commonwealth? The answer seems obvious. It was impossible to prepare an anti-Russian insurrection and explain to people, that a second partition took place, because the king and leaders of the Great Diet had not taken advantage of the possibility of a peaceful settlement of relations with the mighty neighbor from the East ${ }^{54}$.

\footnotetext{
${ }^{51}$ A. Zahorski, Spór o Stanisława Augusta, Warszawa 1988, p. 448.

${ }^{52}$ As quoted in ibidem, p. 58. See also Z. Anusik, Kontrowersje wokół składu..., pp. 108-109.

${ }^{53}$ O ustanowieniu i upadku konstytucji polskiej 3 maja, vol. II, Lwów 1793, pp. 101-102.

${ }^{54}$ See Z. Anu sik, Kontrowersje wokót składu..., p. 109; i d e m, Rzeczpospolita wobec wojny..., p. 184; id e m, Stosunki polsko-pruskie..., p. 230.
} 
At this point, however, another question arises. Why the participation of the Diet's leaders in a planned (at least in the first weeks after the adoption of the Constitution of May 3) political turn to the St. Petersburg court was not adequately reflected in the "Defense of Stanisław August" by Mikołaj Wolski? Why among all widely discussed crimes of leaders of the "Prussian party" the last ruler of the Commonwealth did not accuse them of (which was very important for the future opinion on the last years of his reign) inducing him to return under (perhaps a little weaker) the Russian protectorate? It seems, that the king's reasons where the same, as those of his adversaries, who concealed their participation in a shaping of the Commonwealth's foreign and domestic policy in the final stage of the Great Diet. As a Russian resident on the St. Petersburg court's dime, Stanisław August could not declare (he also mitigated his other statements for censorship reasons), that at a time when he played a truly independent political role in Poland, he did everything in his power to not to allow the restoration of Russia's influence on the Commonwealth's affairs. In such a way (for purely tactical reasons), both sides of the conflict had hided from next generations the core of the problem of the Polish political elites' attitude to negotiations with the St. Petersburg court, which was a key issue from the point of view of interests and international position of the Commonwealth in the final stage of the Great Diet ${ }^{55}$.

Finally, it is worth emphasizing, that a failure of the Polish foreign policy during the last stage of the Great Diet was determined by many different factors. The Berlin court's reluctant and ambiguous position to Poland was only one of them. Even in the beginning of 1792, the future fate of the Commonwealth was not determined. Catherine II decided to send her troops to Poland, only when she was sure of its total isolation on the international stage. It was not Prussia's favorable attitude to Russian intentions, but news of Leopold II's death, the death of Gustav III, and the French war declaration against Austria, that influenced the final decision of the St. Petersburg court the most. The decision, which is worth underlining, that was taken under incentives and influence of false promises made in St. Petersburg by creators of the Targowica

${ }^{55}$ See M. Wolski, op. cit., passim; A. Zahorski, op. cit., pp. 65-112 (here the summery of king's charges pressed on leaders of the Great Diet); Z. An usik, Kontrowersje wokół składu..., pp. 109-110; idem, Stosunki polsko-pruskie..., pp. 230-231; id e m, Rzeczpospolita wobec wojny..., pp. 184-185. 
Confederation ${ }^{56}$. It is obvious, that both the king and leaders of the Diet, had made many significant political mistakes. The most important of them was the conviction, that the Commonwealth could achieve its political objectives, while maintaining neutrality in the face of conflicts at its borders. However, it was noticed in Warsaw, that subsequent pacifications had weakened the international position of the Polish-Lithuanian state. One also realized very soon, that sooner or later an agreement with the St. Petersburg court would be necessary. Leaders of the Diet, who suggested Stanisław August to start negotiations with the empress, did not show any consistency in that matter (similarly to other important state security issues). In the following months, together with the king, they illusorily hoped, that there was still a chance to find some kind of a third solution to the situation, in which the Commonwealth found itself when its prosperity on the international stage ended. The war with Russia in 1792 was also badly fought. No real resistance of the Polish army prevented de facto serious peace negotiations. The military weakness of the Commonwealth, and rapid march of the Russian troops towards Warsaw, were another decisive arguments in the battle between supporters and opponents of the war at the St. Petersburg court ${ }^{57}$. Because of the

56 J. Łojek was of the same opinion, as he stated that: "The St. Petersburg court's opinion on the Constitution of May 3 was unspecified and shaky for months, there were fierce disputes over policy towards Poland among most decisive persons from the court, and the final decision to intervene was made only a few weeks before a real intervention". See ide m, Geneza i obalenie..., pp. 172-174; id e m, Misja Debolego..., pp. 96-138. Emanuel Rostworowski was convinced, that there was no chance of reaching agreement with the St. Petersburg court, because Catherine II did not want to allow the Commonwealth to become independent, and she was supported in that thought by all (without exception) her advisers. See id em, Maj 1791..., p. 28. I do not agree with this statement, as reliable sources quoted earlier deny it as well. I will only add that, in my view, there was a real chance of negotiating such an agreement with the St. Petersburg court, which would guarantee at least some of the Great Diet's reforms. Yet, negotiations with Russia should have been started before the outbreak of the war. I also think, that such negotiations would not have been necessary at all, if the Diet had begun preparations to defend the country not in April 1792, but in the spring of 1789 .

${ }^{57}$ It is worth mentioning here once again, that Alexander A. Bezborodko and Alexander R. Vorontsov were against the war with the Commonwealth, because they were convinced that it would be costly and long-lasting. If the Polish-Lithuanian state had a strong, well-armed, ready-to-fight army of 100 thousand men, Catherine II would certainly listen to them, and there would be probably no war at all. Let us also add, that even during the war there were good chances to negotiate with the St. Petersburg court. If the Commonwealth's army had strongly 
realization of plans put forward to the empress by Zubov's clique, and the diplomatic offensive of the Berlin court, Catherine II finally accepted the idea of the second partition of Poland, which had been consistently suggested to her from the moment the war started.

\section{Bibliography}

\section{Handwriting SOURCES}

The Central Archives of Historical Records in Warsaw (Archiwum Główne Akt Dawnych w Warszawie) [AGAD]

The Public Archives of Potocki's Family

(Archiwum Publiczne Potockich) [APP] No 227.

The Science Library of PAU and PAN in Cracow

(Biblioteka Naukowa PAU i PAN w Krakowie) [BPAU]

manuscript 1652, 1653.

Riksarkivet in Stockholm [RA]

Muscovitica vol. 451, 452, 453.

Polonica vol. 229.

\section{Printed sources}

Głos Jaśnie Wielmożnego Jegomości Tadeusza Kościałkowskiego z Zyndranów, starosty Czotyrskiego, posła Wiłkomierskiego na sesyi seymowey dnia 6 Grudnia 1791 r. miany, Warszawa [1791].

Głos Jego Królewskiej Mości dnia 21 maja roku 1792, [Warszawa 1792].

Kalinka W., Ostatnie lata panowania Stanisława Augusta, $2^{\text {nd }}$ ed., part 2 (Dokumenta do historyi drugiego i trzeciego podziału), Kraków 1891.

O ustanowieniu upadku konstytucji polskiej 3 maja, vol. II, Lwów 1793.

Ostatni poseł polski do Porty Ottomańskiej. Akta legacji stambulskiej Franciszka Piotra Potockiego, ed. K. Waliszewski, vol. I, Paris 1894.

opposed to the Russians, if after a month of war the empress's army had had to fight fiercely in Minsk, Slutsk, and Zhitomir, Bezborodko and his adherents would have gained additional support for Stanisław August's proposals included in his letter to Catherine II. Well-informed Curt von Stedingk believed, that the only chance to save Poland was to appeal to the empress, or to fiercely fight with her troops. The king and leaders of the Diet chose the intermediate route. They began the fight, but too soon ceased to believe in the possibility of the victory and capitulated, when there was still a chance to continue the war. A few weeks more could have prompted the empress to start peace negotiations. That was a crucial political error, which turned out to be the beginning of the end of the First Republic. 
Rok nadziei, rok klęski. Z korespondencji Stanisława Augusta z posłem polskim w Petersburgu Augustynem Deboli, ed. J. Łojek, Warszawa 1974.

Stanislas Poniatowski et Maurice Glayre. Correspondance relative aux partages de la Pologne, ed. E. Mottaz, Paris 1897.

Volumina legum, vol. IX, Kraków 1889.

Wolski M., Obrona Stanisława Augusta, ed. B. Zaleski, "Rocznik Towarzystwa Historyczno-Literackiego w Paryżu”, vol. 1867, Poznań 1867.

\section{STudies}

Anusik Z., Czy dwór berliński proponował Szwecji udział w drugim rozbiorze Polski? Przyczynek do dziejów stosunków politycznych pomiędzy Sztokholmem, Berlinem $i$ Warszawa w latach 1789-1792, [in:] Oświeceni wobec rozbiorów Polski, ed. J. Grobis, Łódź 1998, pp. 43-63.

Anusik Z., Dyplomacja szwedzka wobec kryzysu monarchii we Francji w latach 1787-1792, Łódź 2000.

Anusik Z., Kontrowersje wokół składu personalnego Straży Praw. Wpływ uwarunkowań międzynarodowych na sytuację wewnętrzna $w$ Rzeczypospolitej w ostatniej fazie obrad Sejmu Czteroletniego, [in:] 200 lat Konstytucji 3 Maja. Materiały z konferencji naukowej, ed. M. Pawlak, Bydgoszcz 1992, pp. 93-116.

Anusik Z., Między Warszawa, Sztokholmem i Petersburgiem. Geneza rosyjskiej interwencji $w$ Polsce $w 1792$ r. $w$ świetle korespondencji ambasadora szwedzkiego w Petersburgu Curta von Stedingka, [in:] Przełomy w historii. XVI Powszechny Zjazd Historyków Polskich (Wrocław 15-18 września 1999 roku). Pamiętnik, vol. II, part 1, Toruń 2000, pp. 255-276.

Anusik Z., Misja polska w Sztokholmie w latach 1789-1795, Łódź 1993.

Anusik Z., O polska koronę. Dwór sztokholmski wobec kwestii sukcesji tronu w Polsce $w$ dobie Sejmu Czteroletniego, [in:] Studia i materiały $z$ dziejów nowożytnych, ed. K. Matwijowski, S. Ochmann-Staniszewska, Prace historyczne XIII, Wrocław 1995, pp. 147-167.

Anusik Z., O szwedzki alians. Karta z dziejów stosunków politycznych pomiędzy Sztokholmem a Warszawa $w$ dobie Sejmu Czteroletniego, "Acta Universitatis Lodziensis", Folia Historica 57, 1996, pp. 77-106.

Anusik Z., Organizacja i funkcjonowanie polskiej służby zagranicznej w latach 1764-1792 (próba nowego spojrzenia), "Acta Universitatis Lodziensis", Folia Historica 58, 1996, pp. 49-82.

Anusik Z., Rokowania o polsko-szwedzki traktat sojuszniczy w 1790 roku, "Zapiski Historyczne" 1996, vol. LXI, issue 2-3, pp. 21-44.

Anusik Z., Rzeczpospolita wobec wojny wschodniej (1787-1792) i wojny szwedzko-rosyjskiej (1788-1790), [in:] Polska wobec wielkich konfliktów w Europie nowożytnej. $Z$ dziejów dyplomacji $i$ stosunków międzynarodowych $w$ XV-XVIII wieku, ed. R. Skowron, Kraków 2009, pp. 145-186.

Anusik Z., Stosunki polsko-pruskie $w$ dobie Sejmu Czteroletniego. Kilka refleksji w związku z książka Macieja Kucharskiego, "Przegląd Nauk Historycznych" 2003, vol. II, No. 1 (3), pp. 207-233. 
Anusik Z., Szwedzki rywal Fryderyka Augusta. Gustaw III wobec projektów sukcesji tronu $w$ Polsce w latach 1790-1792, "Rocznik Łódzki” 1997, vol. XLIV, pp. 89-115.

Anusik Z., Wznowienie stosunków dyplomatycznych polsko-szwedzkich u progu obrad Sejmu Czteroletniego, "Acta Universitatis Lodziensis”, Folia Historica 49, 1993, pp. 67-95.

Anusik Z., Stroynowski A., Rybiński Józef Ignacy Tadeusz, [in:] Polski słownik biograficzny, vol. XXXIII, Wrocław-Warszawa-Kraków 1991-1992, pp. 334-338.

Askenazy S., Przymierze polsko-pruskie, ed. 3, Warszawa 1918.

Czeppe M., Orman-Michta E., Sołtyk Stanisław, [in:] Polski słownik biograficzny, vol. XL, Warszawa-Kraków 2000-2001, pp. 424-431.

Dembiński B., Rosya a rewolucya francuska, Kraków 1896.

Grochulska B., Potocki Stanisław Kostka, [in:] Polski słownik biograficzny, vol. XXVIII, Wrocław 1984-1985, pp. 158-170.

Homola I., Kossakowski Józef Dominik, [in:] Polski słownik biograficzny, vol. XIV, Wrocław-Warszawa-Kraków 1967-1968, pp. 274-276.

Kalinka W., Polityka dworu austryackiego w sprawie konstytucyi 3 maja, Kraków 1873.

Kalinka W., Sejm Czteroletni, ed. 4, vol. I-II, Kraków 1895-1896.

Kądziela Ł., Rzewuski Kazimierz, [in:] Polski słownik biograficzny, vol. XXXIV, Wrocław-Warszawa-Kraków 1992-1993, pp. 115-127.

Konopczyński W., Polska a Szwecja. Od pokoju oliwskiego do upadku Rzeczypospolitej 1660-1795, Warszawa 1924.

Krakowski B., Kościałkowski Tadeusz, [in:] Polski słownik biograficzny, vol. XIV, Wrocław-Warszawa-Kraków 1967-1968, pp. 396-397.

Kucharski M., Działalność dyplomacji polskiej $w$ Berlinie $w$ latach 1788-1792, Katowice 2000.

Leśnodorski B., Dzieło Sejmu Czteroletniego (1788-1792). Studium historyczno-prawne, Wrocław 1951.

Lord R.H., Drugi rozbiór Polski, Warszawa 1973.

Łojek J., Geneza i obalenie Konstytucji 3 maja. Polityka zagraniczna Rzeczypospolitej 1787-1792, Lublin 1986.

Łojek J., Misja Debolego w Petersburgu w latach 1787-1792. Z dziejów stosunków polsko-rosyjskich w czasach Sejmu Czteroletniego, Wrocław 1962.

Michalski J., "Warszawa", czyli o antystołecznych nastrojach w czasach Stanisława Augusta, [in:] Warszawa XVIII wieku, issue 1, Warszawa 1972, pp. 9-78.

Michalski J., Dyplomacja polska w latach 1764-1795, [in:] Historia dyplomacji polskiej, vol. II (1572-1795), ed. Z. Wójcik, pp. 483-707.

Nawrot D., Działania dyplomacji polskiej w Wiedniu w latach 1788-1792, Katowice 1999.

Nawrot D., Próba reorientacji polskiej polityki zagranicznej w marcu 1792 r., [in:] Dyplomacja. Polityka. Prawo. Ksiega pamiatkowa ofiarowana Profesorowi Henrykowi Kocójowi $w$ siedemdziesiata rocznicę urodzin, ed. I. Panic, Katowice 2001, pp. 64-73. 
Rostworowski E., Jelski Konstanty, [in:] Polski słownik biograficzny, vol. XI, Wrocław-Warszawa-Kraków 1964-1965, pp. 154-155.

Rostworowski E., Maj 1791 - maj 1792. Rok monarchii konstytucyjnej, Warszawa 1985

Rostworowski E., Ostatni król Rzeczypospolitej. Geneza i upadek Konstytucji 3 maja, Warszawa 1966.

Rostworowski E., Potocki Stanisław Szczęsny, [in:] Polski słownik biograficzny, vol. XXVIII, Wrocław 1984-1985, pp. 183-202.

Smoleński W., Konfederacja targowicka, Kraków 1903.

Smoleński W., Ostatni rok Sejmu Wielkiego, ed. 2, Kraków 1897

Stroynowski A., Patriotyczne wystapienia opozycji na sejmie 1778 r., "Acta Universitatis Lodziensis", Folia Historica 19, 1984, pp. 173-180.

Stroynowski A., Sejmowa opozycja antykrólewska w czasach Rady Nieustajacej (kryteria klasyfikacji), “Acta Universitatis Lodziensis”, Folia Historica 18, 1984, pp. 17-27.

Szczygielski W., Krytyka parlamentarna Rady Nieustajacej $w$ poczatkach obrad Sejmu Wielkiego a problem konstytucyjnej reformy władz wykonawczych panstwa, "Przegląd Nauk Historycznych" 2003, vol. II, No. 2 (4), pp. 67-110.

Szczygielski W., Oświecony elitaryzm w Polsce, "Zeszyty Naukowe Uniwersytetu Łódzkiego", Ser. I, issue 4, 1976, pp. 111-120.

Szczygielski W., Referendum trzeciomajowe. Sejmiki lutowe 1792 roku, Łódź 1994.

Tomkowicz S., Z wieku Stanisława Augusta, Kraków 1882.

Wojakowski J., Straż Praw, Warszawa 1982.

Zahorski A., Spór o Stanisława Augusta, Warszawa 1988.

Zielińska Z., Rzewuski Seweryn, [in:] Polski słownik biograficzny, vol. XXXIV, Wrocław-Warszawa-Kraków 1992-1993, pp. 138-151.

Złomska M., Miaskowski Józef, [in:] Polski słownik biograficzny, vol. XX, Wrocław 1975, pp. 541-542.

Złomska M., Olędzki (Olendzki) Stanisław, [in:] Polski słownik biograficzny, vol. XXIII, Wrocław 1978, pp. 796-797.

\section{Rzeczpospolita wobec Rosji w ostatniej fazie obrad Sejmu Wielkiego (1791-1792)}

$\mathrm{PO}$ uchwaleniu Konstytucji 3 maja ułożenie stosunków z Rosją było najważniejszą kwestią z punktu widzenia bezpieczeństwa Rzeczypospolitej. Widząc wygasanie pomyślnej dla państwa polsko-litewskiego koniunktury w stosunkach międzynarodowych, przywódcy Sejmu Wielkiego zasugerowali Stanisławowi Augustowi dokonanie zwrotu ku Rosji. To z ich inicjatywy król wprowadził do Straży 
Praw kilku stronników dworu petersburskiego. Nie pociagnęło to jednak za soba reorientacji polskiej polityki zagranicznej. Umocniwszy swoja pozycje, Stanisław August zwlekał $z$ nawiązaniem bezpośrednich rozmów $z$ cesarzowa. Był przekonany, że wystarczy nie prowokować Rosjan i łagodzić wszelkie konflikty wewnętrzne, żeby uniknać rosyjskiej interwencji w wewnętrzne sprawy Rzeczypospolitej. Założenie to okazało się błędne. Wbrew twierdzeniu ogromnej większości historyków polskich, którzy uważali, że rosyjska interwencja w Polsce była z góry przesądzona, na dworze petersburskim do ostatniej chwili trwały spory i dyskusje dotyczace kształtu polityki wobec państwa polsko-litewskiego. Część doradców Katarzyny II była zdania, że bez ostatecznego porozumienia $z$ dworami niemieckimi nie należy zaczynać wojny z Rzeczapospolitą, gdyż będzie ona ciężka, długotrwała i kosztowna. Namowy polskich malkontentów sprawiły jednak, że ostatecznie zwyciężyła, lansowana przez faworyta cesarzowej - Płatona A. Zubowa, koncepcja rozpoczęcia działań zbrojnych bez oglądania się na stanowisko Wiednia i Berlina. Bierność dyplomatyczna okazała się fatalnym błędem polskiego króla i jego doradców. Równie błędna była koncepcja prowadzenia wojny w ograniczonym tylko zakresie. Słaby opór polskich armii umacniał bowiem pozycję faworyta cesarzowej. Już w trakcie działań wojennych, po nadejściu do Petersburga listu Stanisława Augusta do Katarzyny II, grupa przeciwników wojny na dworze rosyjskim podjęła ostatnia próbę przerwania działań zbrojnych i podjęcia rozmów $z$ władcą Rzeczypospolitej. Sukcesy wojsk cesarzowej, które w ślad za wycofującymi się Polakami zmierzały szybko w kierunku Warszawy działały jednak na korzyść zwolenników zbrojnej interwencji. Król i jego doradcy zbyt szybko przestali wierzyć w możliwość odniesienia zwycięstwa i skapitulowali w chwili, kiedy wciąż istniały szanse na kontynuowanie wojny, której przedłużenie o kilka tygodni mogło skłonić cesarzową do wyrażenia zgody na rozpoczęcie negocjacji pokojowych. Był to fatalny błąd polityczny, który okazał się w konsekwencji początkiem końca pierwszej Rzeczypospolitej.

Słowa kluczowe: Sejm Wielki, Konstytucja 3 maja, Straż Praw, polityka zagraniczna Rzeczypospolitej, stosunki polsko-rosyjskie w latach 1791-1792. 